\title{
What Determines Financial Development? Culture, Institutions or Trade
}

\author{
Nils Herger, Roland Hodler, and Michael Lobsiger \\ University of Berne; University of Melbourne; University of Berne
}

\begin{abstract}
This paper endeavours to determine in how far theories emphasising cultural values, dysfunctional institutions or impediments to trade can explain the vast differences in the size of financial systems across the globe. To account for endogeneity, an instrumental variables approach is pursued. For a cross-section of countries, we find that trade openness and institutions constraining the political elite from expropriating financiers tend to promote financial development. Conversely, there is only limited evidence that cultural beliefs and the cost of enforcing financial contracts significantly hamper financial development. JEL no. F36, G2, $\mathrm{O} 16$
\end{abstract}

Keywords: Financial development; culture; institutional quality; trade

\section{Introduction}

During the past decades, economic globalisation has had a profound impact upon financial development giving rise to a group of closely intertwined international markets on which banks, corporations and government agencies trade an increasing amount of assets such as bonds, shares or currencies. The transaction cost of accessing external funds has shrunk considerably, which facilitates investment and market entry, exerts competitive pressures to innovate, mobilises savings to accumulate capital, and eventually induces further economic growth (Levine 1997, 2005). Nevertheless, in terms of financial development, considerable heterogeneity continues to exist around the world. For example, for the 1990 to 1999 period, total stock market capitalisation in Hong Kong, Malaysia, and Luxembourg exceeded 100 per

Remark: This paper has benefited from comments by two anonymous referees and participants at the NCCR workshop at the University of Berne and the DEGIT conference in Melbourne. Financial support of the Ecoscientia and the Swiss National Science Foundation is acknowledged with thanks. Research assistance was ably provided by Thierry Graf. Please address correspondence to Nils Herger, Department of Economics, University of Berne, Schanzeneckstrasse 1, CH-3001 Berne, Switzerland; e-mail: nils.herger@vwi.unibe.ch 
cent of GDP; meanwhile many developing countries had not established markets on which equity finance can be raised. Likewise, banking centres such as Japan and Switzerland granted loans in excess of 150 per cent of GDP to their private sector whilst this share amounted to a mere 5 per cent to 10 per cent in many of the least-developed countries (LCDs).

Given the nexus between financial and economic development as well as the relatively high international capital mobility, it is prima facie not clear why such differences in the size of financial systems persist. To date, three broad theories have been proposed to explain the absence of financial development in some countries.

Firstly, according to Stulz and Williamson (2003), cultural heritage may uphold a shared set of widely self-perpetuating values and beliefs even when they hinder financial development. Religions in particular impose numerous rules of moral conduct on matters such as the seeking of enrichment or (illegitimate) financial practices such as usury. Arguably, many religions hold the rights of debtors above those of creditors (Stulz and Williamson 2003: 317) and some of them even demonise the charging of interest rates.

Secondly, institutional theories point out that credibly enforced property rights-e.g. the right of property owners to extract returns on investmentprovide a crucial safeguard in case transactions do not occur instantaneously. Financiers will indeed be reluctant to surrender funds in the face of excessive risks to be confronted with default or expropriation. Against this background, the law and finance theory of La Porta et al. (1997) suggests that legal systems differ markedly in their capacity to proliferate property rights, with the common law, arguably, being superior when it comes to sheltering property owners from being dispossessed (see also Beck et al. 2003). Thus, legal origin matters to the extent that financial transactions rely, as a last resort, on some third party, like the court system, to coerce debtors to honour their financial obligations. However, enforcing arm's-length contracts necessitates the delegation of discretionary power to some authority, which always opens up opportunities for predatory behaviour when bureaucrats, judges, or politicians themselves infringe property rights in order to pocket rents accruing to financial transactions (Acemoglu and Johnson 2005).

Finally, establishing open and transparent financial markets might not always serve the vested interests of the political and economic elite. Though stock markets and banks facilitate business in general, Rajan and Zingales (2003) argue that in countries sheltered from foreign competition, elites with access to government power may be reluctant to loosen their grip 
on the financial system to foreclose market entry and, thus, preserve their economic privileges. In case countries are open to international goods trade, domestic rents are likely to be competed down by foreign firms regardless of the efficiency of domestic financial markets. Indeed, Ades and Di Tella (1999) find corruption, as a particular form of rent-seeking, to be more endemic in countries with modest exports and imports relative to the size of their economy.

Hitherto, empirical studies have assessed the determinants of financial development against the background of individual theories. As regards cultural determinants, Stulz and Williamson (2003) suggest that the principal monotheistic religions such as Catholicism, Islam and Protestantism relate systematically to the establishment and enforcement of creditors' rights and therefore affect the efficiency of the financial system.

La Porta et al. (1997) and Beck et al. (2003) observe that common and civil law systems were spread by means of foreign rule. This permits them to ascribe the comparatively small financial sector in French civil law countries directly to legal origin, without the risk that the causality runs from financial underdevelopment to poor investor protection and legal inefficiency instead.

Stressing the importance of institutionalised constraints that prevent predatory governance, Acemoglu and Johnson (2005) attribute the differences between countries' financial development to colonial strategies, which largely depended on the disease environment encountered by European settlers. In places with relatively modest health hazards for settlement, colonial powers devised similar institutions to those of their native country, preventing the government in particular from having access to excessive levels of power. By way of contrast, territories too hostile for settlement served merely for extracting resources, and institutions were put in place to maximise state income rather than to promote good governance. In former colonies, both the origin of legal institutions, e.g. which power colonised a territory, and institutions to prevent predatory governance, e.g. the colonial strategy pursued by European empires, continue to determine the size of capital markets (Beck et al. 2003). However, constraining government power seems to matter more when explaining financial development (Acemoglu and Johnson 2005).

Finally, in the empirical part of their studies, Rajan and Zingales (2003) as well as Huang and Temple (2005) find the expected positive relationship between trade openness and financial development, at least in countries open to capital flows. However, trade openness might affect financial de- 
velopment through channels other than undermining the opposition of incumbent political and economic elites. For example, according to Do and Levchenko (2007), countries that are abundantly endowed with physical capital might want to specialise in capital-intensive industries to exploit their comparative advantage, which likewise gives rise to the aforementioned trade-finance nexus.

The contribution of the present paper lies in conducting an integrated test on these three broad theories. In particular, we assess the ability of cultural values and beliefs, institutional quality, and trade to explain differences in financial development. To account for direct and indirect methods of finance as well as the size and efficiency of capital markets, measures for financial development include stock market capitalisation, the value of shares traded on stock markets, the amount of bank loans granted to the private sector, and interest-rate margins in the banking industry. Furthermore, possible interdependence among financial development, trade, and institutions is mitigated against by adopting an instrumental variables approach.

The remainder is organised as follows. Section 2 embeds the interrelationships between financial development and its determinants into an econometric model. Section 3 proposes instruments that are exogenous but possess sufficient predicting power for institutional quality, trade openness and economic development. Section 4 assembles variables pertaining to culture, institutions and trade to assess their ability to determine financial development. Further, some robustness exercises are conducted, in particular to check for the role economic development plays when establishing a financial system. The final section summarises and concludes.

\section{An Econometric System for the Determinants of Financial Development}

From the 1960s onwards, many countries around the world have witnessed a marketed rise in the size, breadth and valuation of their financial markets (Rajan and Zingales 2003), which has coincided with a further deepening of international economic integration and efforts to spread institutions enhancing the quality of government. Well-functioning financial markets, institutional quality and trade openness might, thus, be determined simultaneously within a system of structural equations rather than exhibiting 
Figure 1: Path Diagram of Financial Development

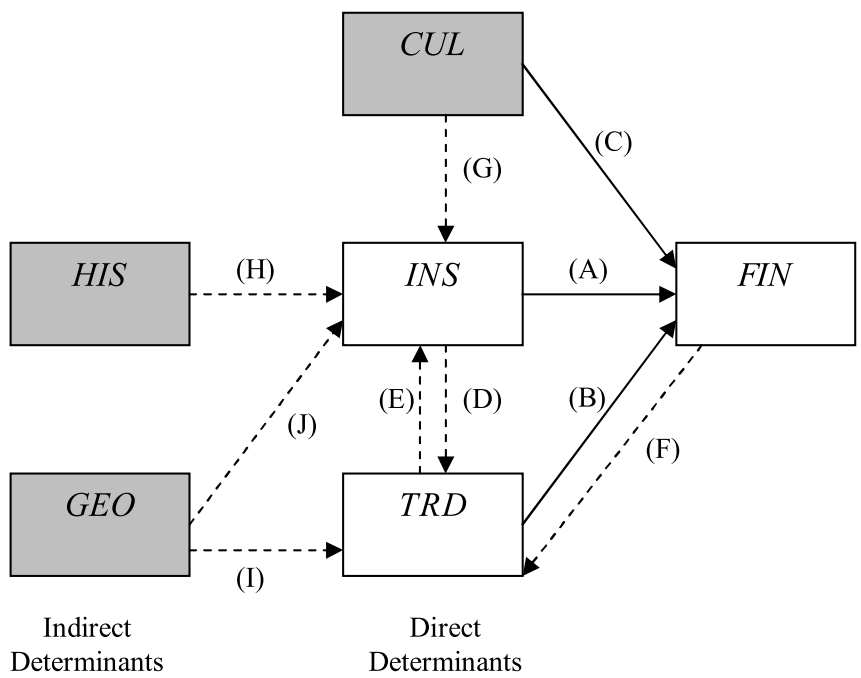

unilateral, cause-effect relationships. The path diagram of Figure 1 endeavours to portray those relationships that feature in the theoretical literature on financial development. ${ }^{1}$

The direct determinants of financial development, depicted by solid arrows, have been discussed above. To recapitulate, a shift from small-scale personal to complex impersonal financial exchanges requires institutions (INS) such as the rule of law or political checks and balances that protect financiers from expropriation (path A). Economic integration provides an alternative way of mitigating against opportunistic behaviour, since trade openness (TRD) tends to erode rents and undermine the political opposition of incumbents to financial development (B). Culture (CUL) directly affects the establishment of financial markets and intermediaries when attitudes are promoted that reduce uncertainties within transactions or beliefs are upheld that sacrifice creditors' or debtors' rights in the name of religion $(\mathrm{C})$.

Some of the determinants of Figure 1 constitute endogenous variables (unshaded boxes) to the extent that they are themselves affected by financial development or depend on some third variable. For example, institutional quality results in lower transaction costs (North 1990: Chapter 4), which in

1 A similar diagram explaining income levels appears in Rodrik et al. (2004). 
turn fosters international trade (D) therefore exhibiting an indirect effect on the financial system. Reversely, open markets can cause sound institutions, e.g. when new ideas travel along trading routes (E). A similar reverse causality as regards the interest group theory occurs when an efficient banking system or stock market facilitates the access to external funds of both domestic and international entrepreneurs and thereby feeds back upon international trade (F). In particular, Feeney and Hillman (2004) as well as Svaleryd and Vlachos (2002) point out that the financial market permits to diversify risk and thus to replace protectionist impediments to trade intended to cushion domestic markets against shocks originating in the global economy.

Turning towards sources of exogenous variation (designated by shaded boxes) upon which no other variable impacts, culture (CUL) may affect the establishment of financial markets indirectly by enhancing institutional quality (G). According to La Porta et al. (1999), religions such as Catholicism and Islam rely on a hierarchically structured organisation to solidify spiritual power, which may breed intolerance towards modernisation and arguably reduces the quality of government (see also Landes 1998: Chapters 11, 24).

Other exogenous factors impacting indirectly upon financial development include colonial history (HIS) and geography (GEO). Some of the vital legal and political institutions safeguarding transactions from the risks of default, fraud, expropriation etc. have been spread around the world through conquest $(\mathrm{H})$. Since institutions typically change only gradually (North 1990), the effect of exogenously imposed institutions might far outlast the occupation by a colonial power.

Despite steady decreases in transportation costs, trade continues to be in essence a neighbourhood phenomenon and, thus, to be closely associated with geographical factors (I). This has been exploited by Frankel and Romer (1999) who construct trade shares from a gravity equation regressing bilateral exchanges onto distance, country size, and other geographical variables. Finally, relating institutional quality to geographical factors $(\mathrm{J})$ rests on the striking fact that most (financially) underdeveloped countries are located within the tropics and subtropics rather than in temperate climate zones. However, we are not aware of any established theory that explains why financial development would be directly related to climatic or ecological conditions.

Similar factors to those of Figure 1 have been considered when testing explanations for the stark differences in economic development, as mea- 
sured by GDP per capita, across the globe. ${ }^{2}$ In particular, economic growth permits a country's residents to build up wealth whilst frictions within the financial system are likely to cause under-investment and, thus, spillover into the real economy in the sense of hampering growth. It should be noted that this argument is not supported unanimously. For example, Lucas (1988: 6) attaches economic growth exclusively to real factors and, thus, argues against a causal impact from financial factors. ${ }^{3}$ Furthermore, some countries differ considerably as regards the stage of their economic and financial development in particular when considering the different methods of finance. ${ }^{4}$ As noted in the outset, the relative size of the banking sector differs considerably, even across developed countries. Furthermore, the relative size of the stock market of some middle income countries (e.g. Chile, Malaysia or South Africa) is more than double compared with some of the highest income countries (e.g. Austria, Denmark or Norway). As the present paper endeavours to test the empirical merits of the three broad theories of financial development discussed at the outset, Figure 1 does not include economic development as a direct determinant of financial development. However, their widely advocated mutual dependence necessitates careful robustness checks on our baseline model.

The relationships of Figure 1 can be restated in the form of structural equations for each endogenous variable. In particular, econometric equations associate financial development,

$$
\alpha_{11} F I N+\alpha_{12} I N S+\alpha_{13} T R D+\beta_{11} C U L=c_{1}+\epsilon_{1},
$$

institutional quality,

$$
\alpha_{22} I N S+\alpha_{23} T R D+\beta_{21} C U L+\beta_{22} G E O+\beta_{23} H I S=c_{2}+\epsilon_{2},
$$

and trade openness,

$$
\alpha_{31} F I N+\alpha_{32} I N S+\alpha_{33} T R D+\beta_{32} G E O=c_{3}+\epsilon_{3},
$$

\footnotetext{
2 See among others, Gallup et al. (1999), Sachs (2003), Dollar and Kraay (2003), Easterly and Levine (2003), Rodrik et al. (2004).

3 See Levine (2005) for an overview of the finance and growth literature.

${ }^{4}$ Indeed, the empirical relationship between economic and financial development is close but far from perfect. The corresponding measures (that are introduced later in more detail) such as the relative size and turnover of the stock market, the amount of loans granted by the banking sector and its overhead cost exhibit a correlation with GDP per capita of $0.58,0.24,0.64$ and -0.41 respectively.
} 
with exogenous variables (CUL, GEO, HIS), whose coefficients are designated by $\beta_{i j}$ with subscripts ij referring to equations and variables respectively, endogenous variables, whose coefficients are designated by $\alpha_{i j}$, stochastic disturbances $\epsilon_{i}$, and an intercept term $c_{i}$. To avoid simultaneous equations bias, financial development (1) needs estimating jointly with (2) and (3) within the structural system,

$$
y^{\prime} A+z^{\prime} B=c^{\prime}+\epsilon^{\prime},
$$

where $y$ is a $1 \times 3$ vector collecting endogenous variables (FIN, INS, TRD) whilst the $1 \times 3$ vector $z$ collects the set of exogenous, or instrumental variables (CUL, GEO, HIS). Matrices $A$ and $B$ contain the structural coefficients, some of which can, however, not be retrieved from (4) since endogenous variables, $y$, do not lend themselves to direct, causal estimation. Instead, institutional quality $(\widehat{I N S})$ and trade openness $(\widehat{T R D})$ can be predicted by means of a two stage-stage least squares procedure (2SLS), which, after transforming (4) into its reduced form,

$$
y^{\prime}=c^{\prime} A^{-1}-z^{\prime} B A^{-1}+\epsilon^{\prime} A^{-1},
$$

regresses endogenous variables first onto underlying instrumental variables. To the extent that the fitted values $(\widehat{I N S})$ and $(\widehat{T R D})$ are highly correlated with their actual counterparts, they serve as good proxies to establish the causal impact of institutional quality and trade openness upon financial development during the second stage.

\section{First-Stage: Instrumental Variables for Institutional Quality, Trade and Economic Development}

This section presents first-stage regressions from endogenous variables such as institutional quality, trade and economic development onto various instrumental variables, which reflect a country's cultural, geographic or historical background. There is a subtle trade-off between representing the mutual dependencies of Figure 1 in a comprehensive manner and keeping models parsimonious to avoid the pitfall of having weak instruments. ${ }^{5}$ The choice of our empirical specification is guided by the desire to employ instruments that exhibit a strong and theoretically underpinned correlation

${ }^{5}$ For a technical discussion on the empirical issues of weak instruments see Staiger and Stock (1997). 
with endogenous determinants of financial development. To this end, we draw on a rich body of recent research that tries to deal with endogeneity in cross-country studies. However, we neither dismiss that some specifications other than ours are conceivable nor advocate that our chosen instruments predetermine directly financial development.

\subsection{Institutional Quality}

As regards the financial system, institutional quality shows up in the degree to which rules lead to the proliferation of investor protection and facilitate the access of entrepreneurs to external funds. Thereby, North (1981) addresses the irony of contracting parties relying on the state to protect financial transactions and the menace that a political elite supposed to oversee financial markets might confiscate economic resources instead, by disentangling a contracting and predatory dimension of institutional quality. Under the contracting view, financiers and entrepreneurs are thought to enter into voluntary agreements to pre-specify property rights and to protect themselves against uncertainties inherent in transactions conducted at arm's length. Likewise, state organisations devised to monitor and enforce property rights constitute the product of mutual consent. Under the predatory view, the state is, however, perceived as an agency receiving fiscal revenue from financiers/entrepreneurs in exchange for granting and safeguarding property rights. Then, institutional quality shows up in the degree to which the rule of law and checks and balances constrain the political elite from pursuing their self-interest by infringing creditors' and debtors' rights.

Following Acemoglu and Johnson (2005), an index on LEGAL FORMALISM $^{6}$ involved in collecting a bounced cheque, which assigns scores to countries from 1 (least cumbersome procedures) to 7 (most cumbersome procedures), measures the quality of contracting institutions. Predatory institutions are reflected by the CONSTRAINTS ON THE EXECUTIVE as measured by a seven category index with higher values designating more constraints. ${ }^{7}$ For both variables, values refer to averages for the 1990s and an overview of their sources and definitions can be found in Table A1 of the Appendix. Note that an increase in LEGAL FORMALISM translates into

\footnotetext{
6 Throughout the remainder, variables employed for estimation appear in CAPITAL letters.

7 Acemoglu and Johnson (2005) label the "vertical" or state-entrepreneur/financier dimension as "property rights" rather than "predatory" institutions.
} 
Table 1: First Stage: Institutional Quality and Economic Development

\begin{tabular}{|c|c|c|c|c|c|}
\hline & \multirow{2}{*}{$\frac{\begin{array}{c}\text { Legal for- } \\
\text { malism }\end{array}}{(1)}$} & \multicolumn{3}{|c|}{ Constraints on executive } & \multirow{2}{*}{$\begin{array}{c}\begin{array}{c}\text { GDP per } \\
\text { capita }\end{array} \\
(5)\end{array}$} \\
\hline & & (2) & (3) & (4) & \\
\hline COMMON LAW & $\begin{array}{c}-0.56^{* * *} \\
(0.08)\end{array}$ & - & - & - & - \\
\hline EUROPEAN LANGUAGE & - & $\begin{array}{c}0.20^{* * *} \\
(0.06)\end{array}$ & - & $\begin{array}{l}0.25^{* *} \\
(0.10)\end{array}$ & - \\
\hline MORTALITY & - & - & $\begin{array}{c}-0.26^{* *} \\
(0.11)\end{array}$ & $\begin{array}{l}-0.21^{*} \\
(0.11)\end{array}$ & - \\
\hline CATHOLIC & $\begin{array}{c}0.26^{* * * *} \\
(0.08)\end{array}$ & - & - & - & - \\
\hline MUSLIM & - & $\begin{array}{c}-0.38^{* * *} \\
(0.07)\end{array}$ & $\begin{array}{c}-0.35^{* * *} \\
(0.09)\end{array}$ & $\begin{array}{c}-0.23^{* *} \\
(0.10)\end{array}$ & - \\
\hline ETHNIC & $\begin{array}{c}0.15 \\
(0.09)\end{array}$ & $\begin{array}{c}-0.18^{* *} \\
(0.09)\end{array}$ & $\begin{array}{c}-0.19^{*} \\
(0.10)\end{array}$ & $\begin{array}{l}-0.17 \\
(0.10)\end{array}$ & - \\
\hline LATITUDE & $\begin{array}{c}-0.25^{* * *} \\
(0.09)\end{array}$ & $\begin{array}{c}0.33^{* * * *} \\
(0.07)\end{array}$ & $\begin{array}{l}0.20^{*} \\
(0.10)\end{array}$ & $\begin{array}{l}0.17^{*} \\
(0.10)\end{array}$ & $\begin{array}{c}0.50^{* * *} \\
(0.08)\end{array}$ \\
\hline LEGAL FORMALISM & - & - & - & - & $\begin{array}{l}-0.10 \\
(0.07)\end{array}$ \\
\hline CONSTRAINTS ON EXECUTIVE & - & - & - & - & $\begin{array}{l}0.23^{* *} \\
(0.09)\end{array}$ \\
\hline CONSTRUCTED TRADE & - & - & - & - & $\begin{array}{c}0.19^{* * *} \\
(0.06)\end{array}$ \\
\hline $\operatorname{Adj} R^{2}$ & 0.46 & 0.54 & 0.42 & 0.47 & 0.59 \\
\hline F-Statistic & 21.96 & 37.75 & 15.51 & 14.74 & 43.61 \\
\hline Observations & 103 & 129 & 82 & 80 & 120 \\
\hline
\end{tabular}

Note: All regressions are cross-sectional. Estimation is by linear least-squares. Table A1 contains definitions and sources of all variables. Standard errors are in parentheses. They are heteroscedasticity robust by the method of White. Coefficients pertain to standardised variables (beta coefficients) and are significant at the 10, 5 and 1 per cent level when labelled with ${ }^{*}, * *$ and ${ }^{* * *}$ respectively.

a decrease in institutional quality whereas the opposite relationship holds for CONSTRAINTS ON THE EXECUTIVE.

The first columns of Table 1 report the estimated impact of various historical, cultural and geographical instruments upon institutional quality. Throughout the remainder, variables have been standardised to enable a direct comparison between the magnitude of estimated coefficients. ${ }^{8}$

8 E.g. coefficients designate the conditional impact of a change of one standard deviation upon the change of the standardised dependent variable. 
Column (1) of Table 1 suggests that COMMON LAW heritage tends to significantly reduce LEGAL FORMALISM thus enhancing contracting institutions, which coincides with the findings of Djankov et al. (2002) in their cross-country study on the cost involved in setting up a firm. COMMON LAW evolves around the resolution of disputes by the courts and is only subsequently encoded into legal principles. As alluded to earlier, the lack of an encompassing legal codification permits judges to focus on the resolution of legal conflicts without having to comply with strict dogmas or potentially burdensome procedural rules. Conversely, the civil law relies on a collection of centrally enacted and authoritative principles, which leave judges with less discretion to resolve disputes on a case-by-case basis. Though this mitigates against judges abusing their discretion, a comprehensive codification, arguably, entails more cumbersome procedures and hence increases the cost of enforcing a contract.

Many of the prominent predatory institutions, such as democracy, checks and balances, or the rule of law that guard against usurpatory state power originated in Western Europe and were spread during the colonial era. Therefore, the affiliation with these institutions relates systematically to the influence foreign powers exerted over a territory, which could be preserved in present-day linguistic conditions (Hall and Jones 1999). We exploit such historical connections to identify the causal effect of predatory institutions on financial development. Estimates of column (2) do indeed find a strong positive relationship between the extent to which EUROPEAN LANGUAGES are spoken and the degree to which a country puts CONSTRAINTS ON THE EXECUTIVE. As already mentioned, mortality rates of European settlers provide another way to quantify the impact of foreign rule and the corresponding spread of institutions mitigating against predatory governance. Despite only relating to former colonies, which reduces the sample by almost 50 observations, settler MORTALITY rates enter the regressions of column (3) in a significant manner with the expected negative sign. Owing to potential effects from multicollinearity, the joint inclusion with EUROPEAN LANGUAGES in column (4) produces only a marginally significant coefficient on settler MORTALITY.

Stulz and Williamson (2003) suggest that religious affiliation ${ }^{9}$ explains some of the differences in investor protection. In particular, compared with Protestantism, Catholic and Muslim belief systems rely arguably more on

9 Unlike Stulz and Williamson (2003), this study follows La Porta et al. (1999) and Beck et al. (2003) by measuring the impact of religions by the proportion of the population af- 
centrally organised hierarchies, which may serve as a model for other social institutions, e.g. when bureaucracies originate in religious ranks. ${ }^{10}$ The proportion of CATHOLIC believers in a country's population does appear to coincide with weaker investor protection and an increase in legal formalities to enforce contracts. Moreover, a rather centralised religious interpretation may run contrary to empowering individuals to adopt an attitude of selfresponsibility and to question religious authority. In particular, column (2) of Table 1 suggests that MUSLIM countries tend to place only modest CONSTRAINTS ON THE EXECUTIVE. Powerful bonds between state and religion provide a potential explanation for this. This result coincides with the finding of La Porta et al. (1999) that countries with a large proportion of MUSLIMS tend to suffer from a rather low quality of government. ${ }^{11}$

For polarised societies finding it more difficult to agree on a set of rules to prevent political elites from having access to an excessive amount of power, Easterly and Levine (1997), La Porta et al. (1999), and Alesina et al. (2003) suggest that ethnically diverse countries suffer from poorer institutional quality. Across our sample of countries, ETHNIC diversity did indeed result in a significant deterioration of predatory but not contracting institutions.

Finally, a country's institutional quality increases in its LATITUDE. Owing to the collinearity between settler MORTALITY and LATITUDE, which reflects the ostensible desire of European colonisers to settle in familiar climatic zones, coefficients are only marginally significant in columns (3) and (4) of Table 1.

To preserve a large number of observations and account for the diversity of countries never subject to colonial rule, the specifications of columns (1) and (2) of Table 1 are employed to extract fitted values on institutional quality $(\widehat{I N S})$. Columns (2) and (4) of Table A2 of the Appendix report, respectively, the constructed scores for LEGAL FORMALISM and CONSTRAINTS ON THE EXECUTIVE, which exhibit a correlation of 0.69 and 0.74 with their actual counterparts. Furthermore, the F-statistic of the first-

filiated to a belief system rather than indicating the predominant religion. Employing alternative measures of religious affiliation however did not affect the essence of the aftermentioned results.

10 For a recent empirical study see La Porta et al. (1999). Landes (1998) provides an economic history of how values and beliefs inherent in religions affect the wealth of nations. 11 Neither PROTESTANT and MUSLIM nor PROTESTANT and CATHOLIC impact upon LEGAL FORMALISM respectively the CONSTRAINTS ON THE EXECUTIVE in a significant manner. Therefore they do not enter the current first-stage regressions. Including them did not alter the essence of the aftermentioned results. 
stage regressions exceeds the threshold value of 10 suggested by Staiger and Stock (1997) to uncover weak instruments. Finally, the pairwise correlation between the fitted values of $\widehat{I N S}$ amounts to -0.14 meaning that contracting and predatory institutions do indeed seem to reflect different dimensions of institutional quality.

\subsection{Trade Openness}

To establish the causal impact of TRADE OPENNESS, measured by imports and exports as a share of GDP, Frankel and Romer (1999) as well as Frankel and Rose (2002) observe that flows in goods and services are in large part associated with geographical proximity and country size. Against this background, Frankel and Rose (2002) extract an exogenous measure for TRADE OPENNESS, which they label CONSTRUCTED TRADE, from the fitted values of a gravity equation regressing bilateral trade flows between country-pairs in 1990 onto the distance between their capital cities, country size in terms of joint area and the population of the target country, a common language and border indicator, as well as whether or not countries are landlocked. Owing to the relationship with geographical factors, this permits to measure the propensity for economic integration free of feedback from e.g. economic or financial development. The F-statistic of 53.86 and a correlation of around 0.5 between actual and constructed levels of trade openness (as reported in columns (5) and (6) of Table A2) suggest that geography offers sufficiently strong instruments to uncover the causal impact of internationally open goods markets upon financial development (see also Frankel and Romer (1999), Frankel and Rose (2002), or Huang and Temple (2005)).

To keep our first-stage model parsimonious and our instruments strong, we have constructed our fitted institutional quality and trade variables independently of one another. Yet, neither including constructed trade openness when extracting institutional quality variables, nor including the fitted institutional quality variables when constructing trade shares, would alter the essence of the aftermentioned results.

\subsection{Economic Development}

Though economic development is not part of the path diagram of Figure 1, its potential interrelationship with financial development poses a serious robustness issue. The final column of Table 1 follows Dollar and Kraay (2003) 
and Rodrik et al. (2004) to relate GDP per capita on a PPP basis with geographical LATITUDE, institutional quality variables, and CONSTRUCTED TRADE shares. ${ }^{12}$ Employing the fitted values for LEGAL FORMALISM and the CONSTRAINTS ON THE EXECUTIVE as reported in columns (2) and (4) of Table A2 avoids potential biases from reverse causality. ${ }^{13}$

Amid the ongoing controversy over whether weak institutions (Rodrik et al. 2004) or geography (Gallup et al. 1999; Sachs 2003) provide the primary reason for the pervasiveness of economic underdevelopment, our estimates suggest that location in low latitude, governments with access to an excessive amount of power, and protectionism are all important factors that undermine economic development. Then again, with an F-statistic of almost 44 and a correlation of 0.78 between actual and fitted values (as reported in columns (7) and (8) of Table A2), present instruments do not suffer from any apparent weakness.

\section{Second Stage: Determinants of Financial Development}

\subsection{Measuring Financial Development}

According to Levine $(1997,2005)$, financial development manifests in the degree to which financial markets and intermediaries reduce the frictions that arise when exchanging funds. In particular, properly working financial systems tend to be more effective in shaping up to their economic purposes such as mobilising capital, allocating funds, monitoring investors, and facilitating the exchange of goods and services. Corresponding direct measures of financial development are, to our knowledge, currently unavailable. To nevertheless establish the causal impact of culture, institutional quality, and trade, four variables reflecting several interrelated dimensions of the

\footnotetext{
12 There is a substantial, but not a perfect overlap between the determinants of economic and financial development. LATITUDE will not be included as a determinant of financial development as we are unaware of any theory suggesting a direct link. Owing to a similar reason, religious variables do not enter the current first-stage regression on economic development. Including religious variables nonetheless (and thus deviating from Dollar and Kraay (2003) and Rodrik et al. (2004)), gives rise to somewhat weaker instruments leaving our subsequently presented results, by and large, unaffected. Of note, their different determinants is consistent with the far from prefect correlation between economic and financial development.

13 The usage of these fitted values makes this technically a second-stage regression. For simplicity, we reserve this term for establishing the link between our explanatory variables and financial development in the next section.
} 
financial system have been sourced from the World Bank's "Database on Financial Development and Structure" and the "World Development Indicators". Following Beck et al. (2003) and Acemoglu and Johnson (2005), these include the relative size of financial markets and intermediaries. In particular, STOCK MARKET CAPITALISATION — that is the total value of shares traded on capital markets relative to GDP — and the total amount of BANK LOANS - that is funds provided by various intermediaries to nongovernmental borrowers relative to GDP-account for direct (or equitybased) and indirect (or debt-based) methods of finance, respectively. ${ }^{14}$ The size of financial markets might partially reflect their effectiveness in delivering the aforementioned functions. However, countries such as Hong Kong, Japan, Singapore, and Switzerland owe their large financial system, at least in part, to their international specialisation in this industry. Furthermore, rather than financial development, large financial systems may also convey elements of inefficiency and overrigid regulation. To address such concerns, we consider the net INTEREST MARGIN (or credit spread) between bank deposits and loans as well as the value of STOCK TRADED relative to GDP as alternative variables for financial development. Finally, extracting a principal component from the four variables suggested allows us to adopt a comprehensive view on FINANCIAL DEVELOPMENT. ${ }^{15}$ The final five columns of Table A2 of the Appendix list our financial development variables.

\subsection{Baseline Results}

Table 2 reports the results of regressing variables pertaining to institutional quality, economic integration, and culture onto financial development variables.

While OLS estimates do not account for the simultaneous relationships of equation (4), two-stage least squares (2SLS) draw on instrumented, rather than actual values of institutional quality and trade openness to prevent

\footnotetext{
14 Instead of BANK LOANS, the results of Beck et al. (2003) as well as Acemoglu and Johnson (2005) draw on the total amount of credit granted to the private sector. Though the credit industry is heavily dominated by indirect methods of finance, the overlap is not perfect. Indeed, capital markets have in the past decade offered ever more possibilities for loan and mortgage sales (and resales). Similarly, bank liabilities provide another indicator for the size of financial intermediation. However, the results mentioned below are, by and large, robust towards these alternative measures.

15 This principal component has been extracted from a sample moment matrix based on correlations.
} 
Herger/Hodler/Lobsiger: What Determines Financial Development?

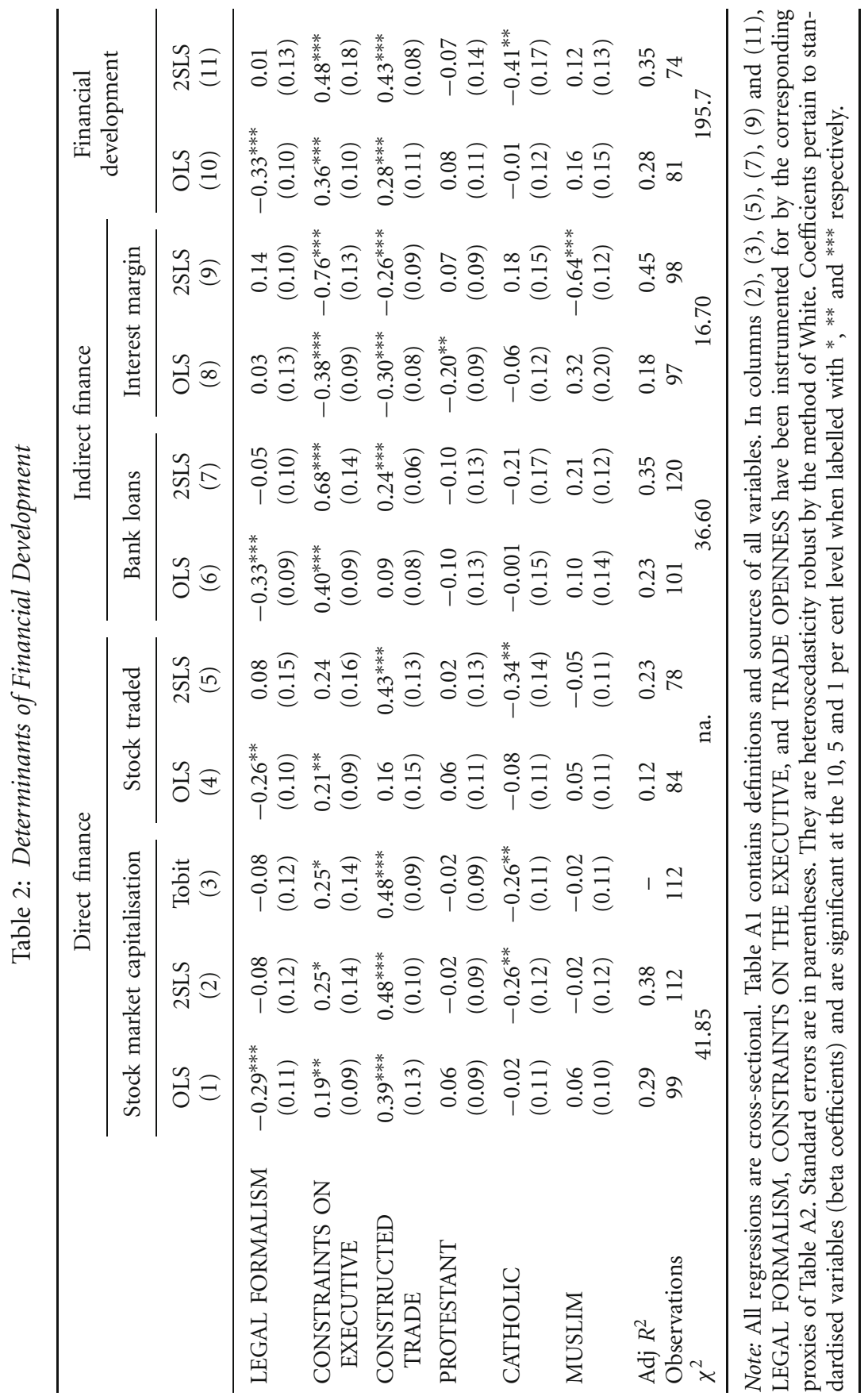


reverse causality. The difference between the coefficients estimated by OLS and 2SLS provides the basis for conducting a Hausman test, which, with $\chi^{2}$ statistics between 16.7 and 195.7 rejects the hypothesis of uncorrelated errors and regressors at least at the 10 per cent level. ${ }^{16}$

Stock market development exhibits properties of a censored variable in the sense that 32 countries of our common sample report a value of zero, ${ }^{17}$ e.g. they do not offer firms the possibility of selling equity on domestic stock exchanges. Therefore, column (3) of Table 2 applies Tobit estimates using instrumental variables suggesting that the results are robust towards such clustered observations. ${ }^{18}$

Coefficients estimated by 2SLS uncover the following insights into the relative explanatory power of the theories under consideration:

Though countries with a large CATHOLIC population seem to have somewhat smaller equity markets, there is only scant evidence that religious values and beliefs provide a causal determinant for financial development. In countries with a large MUSLIM population, financial intermediaries appear even to charge rather low interest margins. This may partly be attributed to the importance of debt finance in those countries. Furthermore, the insignificant coefficients on PROTESTANT do not lend support to the widely held theory that some of its tenets foster capital accumulation.

TRADE OPENNESS tends to enlarge stock markets and the banking system as well as increase trade in stock and reduce interest margins in a highly significant manner. ${ }^{19}$ Furthermore, the magnitudes of the coefficients imply that an increase in trade relative to GDP of one standard deviation increases the development of indirect (or bank-based) and direct (or equity market based) finance by about a quarter and almost half a standard deviation, respectively. These positive entries of economic integration lend support to the interest group theory of Rajan and Zingales (2003), e.g. reducing impediments to trade increases the contestability of domestic markets, reduces monopoly rents, and thereby disciplines domestic elites not to corrupt the benefits of financial development away. However, in countries with com-

\footnotetext{
16 Owing to a non-positive difference between the covariance matrices, the Hausman test statistic could not be computed for STOCK TRADED.

17 Employing standardised values shifts the accumulation of countries from a value of zero towards the corresponding $z$-value.

18 Likewise, STOCK TRADED would be zero in countries without a stock market. However, the corresponding raw data of Beck et al. (2000) do not report a value for this case. 19 Of note, the reversed coefficients on net INTEREST MARGINS mean that a banking system is more efficient in transforming assets in the sense that interest spreads are small.
} 
parative advantages in capital intensive industries, the nexus between the size of financial market and economic integration may be attributed to an increased demand for external funds.

Placing more CONSTRAINTS ON THE EXECUTIVE consistently enhances the relative size and efficiency of the financial system. Similarly to the way in which international economic integration competes away monopoly rents, a high quality of predatory institutions constrains political power that might otherwise be abused by the elite to usurp rents from financial transactions. TRADE OPENNESS and the CONSTRAINTS ON THE EXECUTIVE, hence, may serve the same goal of protecting investors from being dispossessed by a leviathan government emphasising, however, the role of excessive monopoly rents respectively political power as an obstacle to financial development. Furthermore, with a highly significant coefficient estimate of more than two thirds, CONSTRAINTS ON THE EXECUTIVE matter more when it comes to the development of the banking sector, on which TRADE OPENNESS produces only a relatively small coefficient. The quality of predatory institutions exhibits however a smaller and only marginally significant effect on the development of the stock market, which strongly depends on openness to trade. Though international economic integration and solid predatory institutions are both conductive to safeguarding financial transactions, some of the differences in the predominant methods of finance may, thus, be ascribed to the international differences in the prominent mode to protect investors from a leviathan government.

Conversely, contracting institutions inherent in LEGAL FORMALISM exhibit a far smaller impact upon financial development, which fails to be significant when coefficients are estimated by 2SLS. Therefore, the nexus between investor protection and the common law seems not to provide the crucial determinant to explain why some countries remain financially underdeveloped. Though the entries of LEGAL FORMALISM exhibit the expected detrimental impact, financial markets can apparently evolve without the support of adequate contracting institutions (compare Acemoglu and Johnson 2005).

\subsection{Robustness Checks}

The accuracy of two-stage least squares estimates rests primarily on the quality of the instrumental variables employed. Though there is a priori no evidence that the aforementioned results suffer from weak instruments, 
the recent empirical literature on economic and financial development has proposed an array of alternative historical and geographical variables to insulate results from endogeneity bias. Some of these serve in the first columns of Table 3 to run robustness checks on the baseline results. To save space, results refer only to STOCK MARKET CAPITALISATION (for which Tobit results have been calculated) and BANK LOANS. Moreover, first-stage results are not reported here, as the essence of Section 3 carries over when employing alternative instruments.

Column (1) of Table 3 follows Acemoglu and Johnson (2005) as well as Beck et al. (2003) by employing settler MORTALITY rates to predict the quality of predatory institutions. For health hazards to settlers only affect countries that owe their institutions primarily to foreign occupation, this cannot reflect the conditions in former colonising powers as well as countries such as China and Japan, which have never been subject to a formative period of colonial rule.

Sachs (2003) argues that LATITUDE does not account for major geographical factors such as the differences in agricultural productivity of tropical soils compared with soils predominating in temperate zones or the climatic differences between countries located on the west or the east side of a continent. Instead of LATITUDE, column (2) of Table 3 employs the percentage of land in TROPIC zones and column (3) uses the proportion of the population living with the risk of contracting MALARIA as geographical control variable. Against the controversy as regards the importance of geography to explain a country's underdevelopment (Gallup et al. 1999; Sachs 2003; Rodrik et al. 2004), column (4) drops LATITUDE altogether from the set of variables instrumenting for contracting and predatory institutions. Finally, column (5) follows Frankel and Romer (1999) and accounts for within country trade by relying not only on proximity variables between country pairs, but also on POPULATION and the AREA of a country when constructing trade shares.

Employing alternative sets of instrumental variables lends further support to the previous finding that financial underdevelopment tends to arise primarily in countries in which financiers face aggravated risks to be expropriated by the state. Indeed, predatory institutions and international economic integration, respectively, fail only to produce a significant impact upon the size of stock markets when dropping LATITUDE as an instrument in column (4) of Table 3 and when accounting for within-country trade in column (5). Again, predatory institutions and economic integration tend to impact stronger upon, respectively, the size of the banking sector and stock 
Table 3: Robustness Checks I: Alternative Instruments and Samples

\begin{tabular}{|c|c|c|c|c|c|c|c|c|}
\hline & \multirow{2}{*}{$\begin{array}{c}\text { Colonies } \\
\text { Mortal. } \\
\text { (1) }\end{array}$} & \multicolumn{4}{|c|}{ Full sample } & \multirow{2}{*}{$\begin{array}{c}\begin{array}{c}\text { Low } \\
\text { income }\end{array} \\
\\
(6)\end{array}$} & \multirow{2}{*}{$\begin{array}{c}\begin{array}{c}\text { High } \\
\text { income }\end{array} \\
\\
\text { (7) }\end{array}$} & \multirow{2}{*}{$\begin{array}{c}\begin{array}{c}\text { Never } \\
\text { colonised }\end{array} \\
\\
\text { (8) }\end{array}$} \\
\hline & & $\begin{array}{l}\text { Tropic } \\
(2)\end{array}$ & $\begin{array}{c}\text { Malaria } \\
\text { (3) }\end{array}$ & $\begin{array}{l}\text { No } \\
\text { Latit. } \\
(4)\end{array}$ & $\begin{array}{l}\text { Pop, } \\
\text { Area } \\
(5)\end{array}$ & & & \\
\hline & \multicolumn{8}{|c|}{ Stock market capitalisation } \\
\hline LEGAL FORMALISM & $\begin{array}{c}0.03 \\
(0.13)\end{array}$ & $\begin{array}{c}-0.24^{*} \\
(0.14)\end{array}$ & $\begin{array}{l}-0.15 \\
(0.13)\end{array}$ & $\begin{array}{l}-0.04 \\
(0.13)\end{array}$ & $\begin{array}{l}-0.18 \\
(0.12)\end{array}$ & $\begin{array}{l}-0.04 \\
(0.17)\end{array}$ & $\begin{array}{l}-0.02 \\
(0.13)\end{array}$ & $\begin{array}{l}-0.03 \\
(0.15)\end{array}$ \\
\hline $\begin{array}{l}\text { CONSTRAINTS ON } \\
\text { EXECUTIVE }\end{array}$ & $\begin{array}{c}0.43^{* * *} \\
(0.12)\end{array}$ & $\begin{array}{c}0.35^{* * *} \\
(0.16)\end{array}$ & $\begin{array}{c}0.29 * * * \\
(0.10)\end{array}$ & $\begin{array}{c}0.21 \\
(0.14)\end{array}$ & $\begin{array}{l}0.30^{* *} \\
(0.15)\end{array}$ & $\begin{array}{c}0.11 \\
(0.21)\end{array}$ & $\begin{array}{c}0.01 \\
(0.31)\end{array}$ & $\begin{array}{l}0.37 \\
(0.57)\end{array}$ \\
\hline $\begin{array}{l}\text { CONSTRUCTED } \\
\text { TRADF }\end{array}$ & $0.38^{* * *}$ & $0.19^{* *}$ & $0.49^{* * *}$ & $0.48^{* * *}$ & $\begin{array}{l}0.25 \\
(0.16)\end{array}$ & $0.43^{*}$ & $0.38^{* *}$ & $0.50^{* * *}$ \\
\hline PROTESTANT & $\begin{array}{l}-0.12 \\
(0.14)\end{array}$ & $\begin{array}{c}0.14 \\
(0.10)\end{array}$ & $\begin{array}{c}0.11 \\
(0.09)\end{array}$ & $\begin{array}{l}0.03 \\
(0.09)\end{array}$ & $\begin{array}{l}-0.11 \\
(0.10)\end{array}$ & $\begin{array}{l}(0.25) \\
-0.15 \\
(0.15)\end{array}$ & $\begin{array}{l}(0.13) \\
-0.20 \\
(0.13)\end{array}$ & $\begin{array}{c}(0.10) \\
0.17 \\
(0.24)\end{array}$ \\
\hline CATHOLIC & $\begin{array}{c}-0.48^{* * *} \\
(0.15)\end{array}$ & $\begin{array}{l}-0.05 \\
(0.13)\end{array}$ & $\begin{array}{l}-0.13 \\
(0.11)\end{array}$ & $\begin{array}{c}-0.26^{* *} \\
(0.13)\end{array}$ & $\begin{array}{l}-0.24 \\
(0.13)\end{array}$ & $\begin{array}{l}-0.15 \\
(0.23)\end{array}$ & $\begin{array}{c}-0.53^{* * *} \\
(0.18)\end{array}$ & $\begin{array}{l}-0.27 \\
(0.24)\end{array}$ \\
\hline MUSLIM & $\begin{array}{l}-0.15 \\
(0.14)\end{array}$ & $\begin{array}{c}0.11 \\
(0.13)\end{array}$ & $\begin{array}{c}0.08 \\
(0.09)\end{array}$ & $\begin{array}{l}-0.02 \\
(0.12)\end{array}$ & $\begin{array}{l}-0.05 \\
(0.15)\end{array}$ & $\begin{array}{l}-0.26 \\
(0.26)\end{array}$ & $\begin{array}{l}-0.20 \\
(0.25)\end{array}$ & $\begin{array}{c}0.20 \\
(0.43)\end{array}$ \\
\hline $\begin{array}{l}\text { Loglikelihood } \\
\text { Observations }\end{array}$ & $\begin{array}{c}-74.21 \\
70\end{array}$ & $\begin{array}{c}-133.1 \\
107\end{array}$ & $\begin{array}{c}-121.5 \\
111\end{array}$ & $\begin{array}{c}-136.7 \\
116\end{array}$ & $\begin{array}{c}-141.1 \\
112\end{array}$ & $\begin{array}{c}-80.63 \\
62\end{array}$ & $\begin{array}{c}-57.43 \\
49\end{array}$ & $\begin{array}{c}-42.32 \\
35\end{array}$ \\
\hline & \multicolumn{8}{|c|}{ Bank loans } \\
\hline LEGAL FORMALISM & $\begin{array}{l}-0.05 \\
(0.13)\end{array}$ & $\begin{array}{l}-0.11 \\
(0.11)\end{array}$ & $\begin{array}{c}0.02 \\
(0.11)\end{array}$ & $\begin{array}{c}0.01 \\
(0.11)\end{array}$ & $\begin{array}{l}-0.14 \\
(0.10)\end{array}$ & $\begin{array}{l}-0.03 \\
(0.18)\end{array}$ & $\begin{array}{c}0.02 \\
(0.17)\end{array}$ & $\begin{array}{c}0.19 \\
(0.12)\end{array}$ \\
\hline $\begin{array}{l}\text { CONSTRAINTS ON } \\
\text { EXECUTIVE }\end{array}$ & $\begin{array}{c}0.71^{* * *} \\
(0.12)\end{array}$ & $\begin{array}{c}0.62^{* * *} \\
(0.16)\end{array}$ & $\begin{array}{c}0.77^{* * *} \\
(0.16)\end{array}$ & $\begin{array}{c}0.51^{* * *} \\
(0.18)\end{array}$ & $\begin{array}{c}0.70^{* * *} \\
(0.14)\end{array}$ & $\begin{array}{c}0.26 \\
(0.23)\end{array}$ & $\begin{array}{l}0.49^{* *} \\
(0.22)\end{array}$ & $\begin{array}{l}0.35 \\
(0.39)\end{array}$ \\
\hline $\begin{array}{l}\text { CONSTRUCTED } \\
\text { TRADE }\end{array}$ & $\begin{array}{c}0.23^{* * *} \\
(0.08)\end{array}$ & $\begin{array}{l}0.28^{* *} \\
(0.07)\end{array}$ & $\begin{array}{l}0.20^{* *} \\
(0.10)\end{array}$ & $\begin{array}{c}0.28^{* * *} \\
(0.10)\end{array}$ & $\begin{array}{c}0.05 \\
(0.09)\end{array}$ & $\begin{array}{c}0.27 \\
(0.18)\end{array}$ & $\begin{array}{c}0.13 \\
(0.13)\end{array}$ & $\begin{array}{l}0.25^{* *} \\
(0.11)\end{array}$ \\
\hline PROTESTANT & $\begin{array}{c}0.08 \\
(0.14)\end{array}$ & $\begin{array}{l}-0.05 \\
(0.13)\end{array}$ & $\begin{array}{l}-0.06 \\
(0.13)\end{array}$ & $\begin{array}{l}-0.05 \\
(0.13)\end{array}$ & $\begin{array}{l}-0.15 \\
(0.12)\end{array}$ & $\begin{array}{l}-0.05 \\
(0.13)\end{array}$ & $\begin{array}{l}-0.40 \\
(0.27)\end{array}$ & $\begin{array}{l}-0.15 \\
(0.34)\end{array}$ \\
\hline CATHOLIC & $\begin{array}{l}-0.21 \\
(0.20)\end{array}$ & $\begin{array}{l}-0.25 \\
(0.21)\end{array}$ & $\begin{array}{c}-0.37^{*} \\
(0.20)\end{array}$ & $\begin{array}{l}-0.27 \\
(0.18)\end{array}$ & $\begin{array}{l}-0.19 \\
(0.17)\end{array}$ & $\begin{array}{l}-0.11 \\
(0.23)\end{array}$ & $\begin{array}{c}-0.57 \\
(0.34)\end{array}$ & $\begin{array}{l}-0.34 \\
(0.37)\end{array}$ \\
\hline MUSLIM & $\begin{array}{l}0.29^{*} \\
(0.17)\end{array}$ & $\begin{array}{c}0.15 \\
(0.12)\end{array}$ & $\begin{array}{l}0.21^{* *} \\
(0.11)\end{array}$ & $\begin{array}{c}0.09 \\
(0.12)\end{array}$ & $\begin{array}{c}0.19 \\
(0.13)\end{array}$ & $\begin{array}{c}0.21 \\
(0.31)\end{array}$ & $\begin{array}{l}-0.10 \\
(0.25)\end{array}$ & $\begin{array}{l}-0.17 \\
(0.21)\end{array}$ \\
\hline Adj $R^{2}$ & 0.48 & 0.41 & 0.38 & 0.25 & 0.30 & 0.12 & 0.16 & 0.03 \\
\hline Observations & 74 & 109 & 113 & 124 & 120 & 66 & 54 & 35 \\
\hline
\end{tabular}

Note: All regressions are cross-sectional. Table A1 contains definitions and sources of all variables. Estimation is by 2SLS with instruments being taken from Table A2. Estimates of the top panel account for the censored nature of STOCK MARKET CAPITALISATION. Standard errors are in parentheses. They are heteroscedasticity robust by the method of White. Coefficients pertain to standardised variables (beta coefficients) and are significant at the 10, 5 and 1 per cent level when labelled with ${ }^{*}, * *$ and ${ }^{* * *}$ respectively.

markets. Meanwhile, the quality of the legal protection and enforcement of property rights within the contractual relationship between financier and entrepreneur appears not to be imperative for establishing well-functioning 
financial systems. Then again, there is some evidence that CATHOLIC countries have somewhat smaller capital markets and Islamic countries tend to rely more on debt finance.

Following Huang and Temple (2005), columns (6) and (7) uncover some heterogeneity in the degree to which determinants affect financial development in low and lower-middle income countries as well as high and upper middle-income countries. Given the reduced number of observations and the lower variability in the CONSTRAINTS ON THE EXECUTIVE within these country-groups, a weaker impact upon BANK LOANS is to be expected. Nevertheless, this effect remains significant in the group of high and upper middle-income countries. CONSTRUCTED TRADE shares continue to affect financial development in a significantly positive manner when it comes to direct, equity based finance. For low-income countries, this concurrence between internationally open markets and financial development is unlikely to result from an increased demand for financial services by export-orientated industries specialising in capital intensive production, as advocated by Do and Levchenko (2007).

Ascribing institutional development primarily to European history gives rise to a somewhat ethnocentric view. Therefore, the final column of Table 3 re-estimates the baseline results for countries never subject to colonial rule. Albeit this reduces the sample to a mere 35 observations, the positive relationship between the degree to which a country's markets are open to international trade and financial development is preserved.

Acemoglu and Johnson (2005: 967-975) consider alternative indices for institutional quality such as the RISK OF EXPROPRIATION on foreign direct investments and PRIVATE PROPERTY RIGHTS to measure the quality of predatory institutions, as well as the PROCEDURAL COMPLEXITY and the NUMBER OF PROCEDURES involved in collecting commercial debt to measure the quality of contracting institutions. Table 4 reports the results when different indices are employed to proxy for institutionalised investor protection. Once again, this backs up the essence of our previous results.

The final column of Table 4 employs predicted income per capita as reported in column (8) of Table A2 to check in how far our results are sensitive towards a possible interrelationship between financial and economic development. For both indirect and direct methods of finance, international economic integration continues to affect financial development in the aforementioned manner. Together with the separate results of Table 3 for low and high-income countries, this lends further support to the view that constraining the state to infringe investor protection lies at the origin 
Table 4: Robustness Checks II: Alternative Covariates

\begin{tabular}{|c|c|c|c|c|c|}
\hline & (1) & (2) & (3) & (4) & (5) \\
\hline & \multicolumn{5}{|c|}{ Stock market capitalisation } \\
\hline PROCEDURAL COMPL. & $\begin{array}{l}-0.11 \\
(0.12)\end{array}$ & - & $\begin{array}{l}-0.10 \\
(0.13)\end{array}$ & - & - \\
\hline NO. OF PROCEDURES & - & $\begin{array}{l}-0.02 \\
(0.15)\end{array}$ & - & $\begin{array}{l}-0.06 \\
(0.15)\end{array}$ & - \\
\hline LEGAL FORMALISM & - & - & - & - & $\begin{array}{l}-0.09 \\
(0.13)\end{array}$ \\
\hline RISK OF EXPROPRI. & $\begin{array}{l}-0.16 \\
(0.10)\end{array}$ & - & - & $\begin{array}{l}-0.15 \\
(0.17)\end{array}$ & $\begin{array}{l}- \\
-\end{array}$ \\
\hline PRIVATE PROP. RIGHTS & - & $\begin{array}{c}0.18 \\
(0.17)\end{array}$ & $\begin{array}{c}0.17 \\
(0.10)\end{array}$ & - & - \\
\hline CONSTR. EXECUT. & - & - & - & - & $\begin{array}{c}0.38 \\
(0.35)\end{array}$ \\
\hline CONSTRUCTED TRADE & $\begin{array}{c}0.48^{* * *} \\
(0.09)\end{array}$ & $\begin{array}{c}0.50^{* * *} \\
(0.10)\end{array}$ & $\begin{array}{c}0.48^{* * *} \\
(0.10)\end{array}$ & $\begin{array}{c}0.49^{* * *} \\
(0.10)\end{array}$ & $\begin{array}{c}0.50^{* * *} \\
(0.12)\end{array}$ \\
\hline PROTESTANT & $\begin{array}{l}-0.01 \\
(0.09)\end{array}$ & $\begin{array}{l}-0.01 \\
(0.09)\end{array}$ & $\begin{array}{l}-0.02 \\
(0.09)\end{array}$ & $\begin{array}{c}-0.004 \\
(0.09)\end{array}$ & $\begin{array}{l}-0.02 \\
(0.09)\end{array}$ \\
\hline CATHOLIC & $\begin{array}{c}-0.20^{*} \\
(0.11)\end{array}$ & $\begin{array}{c}-0.28^{* * *} \\
(0.10)\end{array}$ & $\begin{array}{c}-0.22^{*} \\
(0.12)\end{array}$ & $\begin{array}{c}-0.26^{* *} \\
(0.10)\end{array}$ & $\begin{array}{c}-0.28^{* *} \\
(0.13)\end{array}$ \\
\hline MUSLIM & $\begin{array}{l}-0.11 \\
(0.09)\end{array}$ & $\begin{array}{l}-0.14 \\
(0.09)\end{array}$ & $\begin{array}{l}-0.14 \\
(0.09)\end{array}$ & $\begin{array}{l}-0.11 \\
(0.09)\end{array}$ & $\begin{array}{c}0.03 \\
(0.18)\end{array}$ \\
\hline GDP PER CAPITA & - & - & - & - & $\begin{array}{l}-0.11 \\
(0.28)\end{array}$ \\
\hline $\operatorname{Adj} R^{2}$ & 0.37 & 0.37 & 0.37 & 0.37 & 0.37 \\
\hline \multirow[t]{2}{*}{ Observations } & 112 & 112 & 112 & 112 & 112 \\
\hline & \multicolumn{5}{|c|}{ Bank loans } \\
\hline PROCEDURAL COMPL. & $\begin{array}{l}-0.10 \\
(0.10)\end{array}$ & - & $\begin{array}{l}-0.07 \\
(0.10)\end{array}$ & - & - \\
\hline NO. OF PROCEDURES & - & $\begin{array}{l}-0.03 \\
(0.13)\end{array}$ & - & $\begin{array}{c}-0.07- \\
(0.12)\end{array}$ & - \\
\hline LEGAL FORMALISM & - & - & - & - & $\begin{array}{l}-0.03 \\
(0.10)\end{array}$ \\
\hline RISK OF EXPROPRI. & $\begin{array}{c}-0.51^{* * *} \\
(0.10)\end{array}$ & - & - & $\begin{array}{c}-0.48^{* * *} \\
(0.12)\end{array}$ & - \\
\hline PRIVATE PROP. RIGHTS & - & $\begin{array}{c}0.48^{* * *} \\
(0.12)\end{array}$ & $\begin{array}{c}0.49^{* * *} \\
(0.10)\end{array}$ & - & - \\
\hline CONSTR. EXECUT. & - & - & - & - & $\begin{array}{c}0.24 \\
(0.30)\end{array}$ \\
\hline CONSTRUCTED TRADE & $\begin{array}{c}0.25^{* * *} \\
(0.06)\end{array}$ & $\begin{array}{c}0.26^{* * *} \\
(0.07)\end{array}$ & $\begin{array}{c}0.25^{* * *} \\
(0.06)\end{array}$ & $\begin{array}{c}0.25^{* * *} \\
(0.07)\end{array}$ & $\begin{array}{c}0.16^{* * *} \\
(0.07)\end{array}$ \\
\hline PROTESTANT & $\begin{array}{l}-0.10 \\
(0.13)\end{array}$ & $\begin{array}{l}-0.10 \\
(0.13)\end{array}$ & $\begin{array}{l}-0.10 \\
(0.13)\end{array}$ & $\begin{array}{l}-0.09 \\
(0.13)\end{array}$ & $\begin{array}{l}-0.10 \\
(0.13)\end{array}$ \\
\hline CATHOLIC & $\begin{array}{l}-0.10 \\
(0.16)\end{array}$ & $\begin{array}{l}-0.19 \\
(0.14)\end{array}$ & $\begin{array}{l}-0.15 \\
(0.17)\end{array}$ & $\begin{array}{l}-0.14 \\
(0.13)\end{array}$ & $\begin{array}{l}-0.13 \\
(0.19)\end{array}$ \\
\hline MUSLIM & $\begin{array}{l}-0.01 \\
(0.14)\end{array}$ & $\begin{array}{l}-0.10 \\
(0.14)\end{array}$ & $\begin{array}{l}-0.10 \\
(0.14)\end{array}$ & $\begin{array}{l}-0.02 \\
(0.14)\end{array}$ & $\begin{array}{c}0.03 \\
(0.14)\end{array}$ \\
\hline GDP PER CAPITA & - & - & - & - & $\begin{array}{l}0.37^{*} \\
(0.21)\end{array}$ \\
\hline Adj $R^{2}$ & 0.36 & 0.36 & 0.36 & 0.36 & 0.35 \\
\hline Observations & 120 & 120 & 120 & 120 & 120 \\
\hline $\begin{array}{l}\text { Note: All regressions are cro } \\
\text { 2SLS with instruments bein } \\
\text { STOCK MARKET CAPITA } \\
\text { method of White. Coefficie } \\
\text { and } 1 \text { per cent level when } 1\end{array}$ & $\begin{array}{l}\text { Table A1 } \\
\mathrm{m} \text { Table } \\
\text { Standard } \\
\text { to standa } \\
*, * * \text { an }\end{array}$ & $\begin{array}{l}\text { ins defini } \\
\text { imates of } \\
\text { are in par } \\
\text { variables } \\
\text { espectively }\end{array}$ & $\begin{array}{l}\text { and sour } \\
\text { op panel } \\
\text { ses. They } \\
\text { coefficien }\end{array}$ & $\begin{array}{l}\text { all variable } \\
\text { at for the } \\
\text { teroscedast } \\
\text { d are signi }\end{array}$ & $\begin{array}{l}\text { mation is } \\
\text { ed nature } \\
\text { obust by } \\
\text { at the } 10\end{array}$ \\
\hline
\end{tabular}


of financial development when it comes to the ability of international trade to undermine an elite's incentives to foreclose financial markets for rent seeking purposes. Conversely, predatory institutions also fail to affect the development of the banking sector in a significant manner. The establishment of a sound political and legal framework constraining public power thus appears to foster financial development, at least in part, via economic development.

We have tried further specifications. For example, Easterly and Levine (1997) advocate that ethnic diversity lies at the origin of underdevelopment. Therefore, we have included ETHNIC as a direct determinant for financial development, which resulted in an insignificant coefficient and did not affect the essence of the present results. Some scholars view macroeconomic stability as an important impetus for a thriving financial system. To consider this, we have added variables such as INFLATION, the size of GOVERNMENT, or EXCHANGE rate overvaluation to our baseline specification. Then again, macroeconomic conditions appear not to have had a causal effect on STOCK MARKET CAPITALISATION and BANK LOANS both in terms of insignificant entries and the continued support of predatory institutions and trade as financial development determinants.

\section{Concluding Remarks}

By drawing together theories emphasising the role of cultural values and beliefs, dysfunctional institutions, or impediments to trade as obstacles to financial development, this paper has endeavoured to shed more light on the reasons why malfunctioning financial systems beset many countries around the globe. For this purpose, we have employed two-stage least squares to compare the causal effects of the determinants proposed by theory. A relatively clear picture emerged even though none of these determinants proved to be robust to all specifications considered: Financiers seem to be reluctant to surrender funds in countries where they face aggravated risks of an infringement of their property right by the state. In particular, opening markets to international trade tends to foster domestic competition and, thus, undermine the incentives of domestic elites to appropriate rents by expropriating financiers. Institutionalised constraints to prevent predatory governance appear to provide a further safeguard to secure financial transactions. While international economic integration has a relatively strong effect on stock market development, predatory institutions matter more when it 
comes to developing a banking sector. Conversely, contracting institutions seem to be less important insofar as financial systems can apparently thrive without the support of public enforcement. Ostensibly, investors can (at least in part) turn to private measures such as offering collateral or building up a reputation as honourable contracting partner in countries lacking a reliable legal system. Aside from Catholic countries having somewhat smaller equity markets, there is only scant evidence that religious values and beliefs directly undermine the establishment of an effective financial system.

Two-stage least squares attribute endogenous variables such as institutional quality or trade to exogenous factors such as culture, colonial history, or geography before evaluating their impact upon the size of stock and credit markets. This, however, does not imply that exogenous factors predetermine financial development but merely constitutes a statistical procedure to offset reverse causality. In particular, different countries have pursued different strategies relying, e.g. more on checks and balances, reducing impediments to trade, or fostering democratic accountability to prevent rent-seeking governance. However, implementing any policy that prevents abuses of public power for private benefit could be highly beneficial when financiers face a lower risk to be expropriated and thus surrender more funds towards new businesses, which in turn tends to foster economic growth.

\section{Appendix}

Table A1: Description of the Data Set

\begin{tabular}{lll}
\hline Variable & \multicolumn{1}{c}{ Description } & \multicolumn{1}{c}{ Source } \\
\hline BANK LOANS & $\begin{array}{l}\text { Size of the banking system as a fraction of the GDP. } \\
\text { It includes all credit to various sectors on a gross } \\
\text { basis, with the exception of credit to the central from } \\
\text { government, which is net. The banking sector in- } \\
\text { cludes monetary authorities, deposit money banks, } \\
\text { and other banking institutions for which data are } \\
\text { available (including institutions that do not accept } \\
\text { transferable deposits but do incur such liabilities). }\end{array}$ \\
\hline CATHOLIC & $\begin{array}{l}\text { Share of the population affiliated to Catholicism in } \\
\text { 2001. }\end{array}$ & $\begin{array}{l}\text { Encyclopedia } \\
\text { Britannica, 2001 }\end{array}$ \\
\hline
\end{tabular}


Table A1: continued

\begin{tabular}{|c|c|c|}
\hline Variable & Description & Source \\
\hline $\begin{array}{l}\text { CONSTRAINTS } \\
\text { ON EXECU- } \\
\text { TIVE }\end{array}$ & $\begin{array}{l}\text { Index on the institutional limitations put on the ex- } \\
\text { ecutive authority. Index scores range from } 0 \text { to } 7 \\
\text { with higher values designating more constraints on } \\
\text { exerting executive power. }\end{array}$ & $\begin{array}{l}\text { Acemoglu and } \\
\text { Johnson (2005) }\end{array}$ \\
\hline $\begin{array}{l}\text { CONSTRUCTED } \\
\text { TRADE }\end{array}$ & $\begin{array}{l}\text { Trade openness extracted from a gravity equation } \\
\text { on distance, country size, and other geographical } \\
\text { controls. }\end{array}$ & $\begin{array}{l}\text { Frankel and Rose } \\
(2002)\end{array}$ \\
\hline ETHNIC & $\begin{array}{l}\text { Ethnic fractionalisation computed for the years } \\
1965-1995 \text { as one minus the Herfindahl index of } \\
\text { ethnic group shares (Ethnic }=1-\sum s^{2} \text { ) reflect- } \\
\text { ing the probability that two randomly selected } \\
\text { individuals belong to different ethnolinguistic } \\
\text { groups. }\end{array}$ & $\begin{array}{l}\text { Alesina et al. } \\
(2003)\end{array}$ \\
\hline $\begin{array}{l}\text { EUROPEAN } \\
\text { LANGUAGE }\end{array}$ & $\begin{array}{l}\text { Fraction of the population speaking one of the ma- } \\
\text { jor languages of Western Europe: English, French, } \\
\text { German, Portuguese or Spanish. }\end{array}$ & $\begin{array}{l}\text { Hall and Jones } \\
\text { (1999) }\end{array}$ \\
\hline EXCHANGE & $\begin{array}{l}\text { An index of real overvaluation of the official ex- } \\
\text { change rate in } 1960-1976 .\end{array}$ & $\begin{array}{l}\text { Acemoglu and } \\
\text { Johnson }(2005)\end{array}$ \\
\hline $\begin{array}{l}\text { GDP PER } \\
\text { CAPITA }\end{array}$ & $\begin{array}{l}\text { GDP per capita on constant } 2000 \text { international US } \\
\text { dollar (PPP) basis. }\end{array}$ & WDI \\
\hline GOVERNMENT & $\begin{array}{l}\text { Average of the ratio of real government consump- } \\
\text { tion expenditure to real GDP from } 1970 \text { to } 1989 \text {. }\end{array}$ & $\begin{array}{l}\text { Acemoglu and } \\
\text { Johnson }(2005)\end{array}$ \\
\hline INFLATION & $\begin{array}{l}\text { Annual average inflation in the Consumer Price In- } \\
\text { dex from } 1970 \text { to } 1998 .\end{array}$ & $\begin{array}{l}\text { Acemoglu and } \\
\text { Johnson }(2005)\end{array}$ \\
\hline $\begin{array}{l}\text { INTEREST } \\
\text { MARGIN }\end{array}$ & $\begin{array}{l}\text { Measure of the efficiency of the banking sector to } \\
\text { channel funds from savers to investors. The net } \\
\text { interest margin equals the accounting value of } \\
\text { a bank's net interest revenue as a share of its total } \\
\text { assets. The net interest revenue equals a bank's } \\
\text { interest income minus interest expenses. }\end{array}$ & Beck et al. (2000) \\
\hline LATITUDE & $\begin{array}{l}\text { Country's distance from the equator scaled to take } \\
\text { values between } 0 \text { and } 1 \text {, where } 0 \text { designates the loca- } \\
\text { tion of the equator and } 1 \text { designates the poles. }\end{array}$ & $\begin{array}{l}\text { La Porta et al. } \\
\text { (1999) }\end{array}$ \\
\hline $\begin{array}{l}\text { LEGAL FOR- } \\
\text { MALISM }\end{array}$ & $\begin{array}{l}\text { Index of formality in legal procedures for collecting } \\
\text { a bounced cheque in } 2004 \text {. Index scores range be- } \\
\text { tween } 1 \text { and } 7 \text { with higher values designating more } \\
\text { legal formalism. }\end{array}$ & $\begin{array}{l}\text { Acemoglu and } \\
\text { Johnson }(2005)\end{array}$ \\
\hline MALARIA & Population living in areas with malaria in 1994. & $\begin{array}{l}\text { Gallup et al. } \\
\text { (1999) }\end{array}$ \\
\hline
\end{tabular}


Table A1: continued

\begin{tabular}{|c|c|c|}
\hline Variable & Description & Source \\
\hline MORTALITY & $\begin{array}{l}\text { Estimated mortality of European settlers in colonies } \\
\text { before } 1850 \text { (logarithmic scale). Mortality rates re- } \\
\text { fer to European-born soldiers, sailors, and bishops } \\
\text { when stationed in colonies. It measures the effects } \\
\text { of local diseases on people without inherited or ac- } \\
\text { quired immunities. }\end{array}$ & $\begin{array}{l}\text { Acemoglu et al. } \\
(2001)\end{array}$ \\
\hline MUSLIM & Share of the population affiliated to Islam in 2001. & $\begin{array}{l}\text { Encyclopedia } \\
\text { Britannica, } 2001\end{array}$ \\
\hline $\begin{array}{l}\text { NUMBER OF } \\
\text { PROCEDURES }\end{array}$ & $\begin{array}{l}\text { Number of procedures involved in collecting com- } \\
\text { mercial debt in } 2004 \text {. }\end{array}$ & $\begin{array}{l}\text { Acemoglu and } \\
\text { Johnson (2005) }\end{array}$ \\
\hline POP & Population of a country. & WDI \\
\hline $\begin{array}{l}\text { PROCEDURAL } \\
\text { COMPLEXITY }\end{array}$ & $\begin{array}{l}\text { Index of complexity in collecting commercial debt } \\
\text { in } 2004 \text {. Index scores range from } 0 \text { to } 10 \text { with higher } \\
\text { values designating more complex procedures. }\end{array}$ & $\begin{array}{l}\text { Acemoglu and } \\
\text { Johnson (2005) }\end{array}$ \\
\hline $\begin{array}{l}\text { PROPERTY } \\
\text { RIGHTS }\end{array}$ & $\begin{array}{l}\text { Index on the protection of private property. Index } \\
\text { scores range from } 0 \text { to } 7 \text { with higher values desig- } \\
\text { nating more secure property rights. }\end{array}$ & $\begin{array}{l}\text { Heritage Foun- } \\
\text { dation }\end{array}$ \\
\hline PROTESTANT & $\begin{array}{l}\text { Share of the population affiliated to Protestantism } \\
\text { in } 2001 .\end{array}$ & $\begin{array}{l}\text { Encyclopedia } \\
\text { Britannica, } 2001\end{array}$ \\
\hline $\begin{array}{l}\text { RISK OF EX- } \\
\text { PROPRIATION }\end{array}$ & $\begin{array}{l}\text { Index on the risk of expropriation of private foreign } \\
\text { investment by the government in terms of average } \\
\text { over the years } 1985-1995 \text {. Index scores range from } \\
0 \text { to } 10 \text {. To make the results more intuitive, scores } \\
\text { have been reversed with higher values designating } \\
\text { more risk. }\end{array}$ & $\begin{array}{l}\text { Political Risk } \\
\text { Service }\end{array}$ \\
\hline $\begin{array}{l}\text { STOCK } \\
\text { TRADED }\end{array}$ & Value of traded stock relative to GDP. & WDI \\
\hline $\begin{array}{l}\text { STOCK MAR- } \\
\text { KET CAPITAL- } \\
\text { ISATION }\end{array}$ & $\begin{array}{l}\text { Average market value of all traded stocks as a frac- } \\
\text { tion of GDP. }\end{array}$ & $\begin{array}{l}\text { Compiled from } \\
\text { WDI }\end{array}$ \\
\hline $\begin{array}{l}\text { TRADE OPEN- } \\
\text { NESS }\end{array}$ & $\begin{array}{l}\text { International economic integration measured by cu- } \\
\text { mulated exports and imports as a share of real GDP } \\
\text { per capita (calculated with the Laspeyres method). }\end{array}$ & $\begin{array}{l}\text { Penn World } \\
\text { Table Version } 6.1\end{array}$ \\
\hline TROPIC & $\begin{array}{l}\text { Land surface located in tropical climatic zone } \\
\text { (defined after the classification of Koeppen and } \\
\text { Geiger). }\end{array}$ & $\begin{array}{l}\text { Gallup et al. } \\
\text { (1999) }\end{array}$ \\
\hline
\end{tabular}

Note: This table summarises the data set collected for up to 129 countries as averages over the 1990s unless otherwise stated. 


\section{Table A2: Basic Data}

High and Upper Middle Income Countries (as defined by the World Bank)

\begin{tabular}{|c|c|c|c|c|c|c|c|c|c|c|c|c|c|}
\hline \multirow[t]{2}{*}{ Country } & \multicolumn{2}{|c|}{$\begin{array}{l}\text { Contracting } \\
\text { institutions }\end{array}$} & \multicolumn{2}{|c|}{$\begin{array}{l}\text { Predatory } \\
\text { institutions }\end{array}$} & \multicolumn{2}{|c|}{$\begin{array}{c}\text { Trade } \\
\text { openness }\end{array}$} & \multicolumn{2}{|c|}{$\begin{array}{l}\text { GDP per } \\
\text { capita }\end{array}$} & \multirow{2}{*}{$\begin{array}{l}\text { Bank } \\
\text { loans } \\
(9)\end{array}$} & \multirow{2}{*}{$\begin{array}{l}\text { Net } \\
\text { interest } \\
\text { diff. } \\
(10)\end{array}$} & \multirow{2}{*}{$\begin{array}{l}\text { Stock } \\
\text { market } \\
\text { capital. } \\
\text { (11) }\end{array}$} & \multirow{2}{*}{ 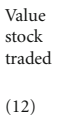 } & \multirow{2}{*}{$\begin{array}{l}\text { Finan. } \\
\text { dev. }\end{array}$} \\
\hline & $\begin{array}{l}\text { Actu. } \\
\text { (1) }\end{array}$ & $\begin{array}{l}\text { Constr. } \\
\text { (2) }\end{array}$ & $\begin{array}{l}\text { Actu. } \\
\text { (3) }\end{array}$ & $\begin{array}{l}\text { Constr. } \\
\text { (4) }\end{array}$ & $\begin{array}{l}\text { Actu. } \\
\text { (5) }\end{array}$ & $\begin{array}{l}\text { Constr. } \\
(6)\end{array}$ & $\begin{array}{l}\text { Actu. } \\
(7)\end{array}$ & $\begin{array}{l}\text { Constr. } \\
(8)\end{array}$ & & & & & \\
\hline Argentina & 5.40 & 4.39 & 5.18 & 6.57 & 0.18 & 0.03 & 10,136 & 9,749 & 0.28 & 0.07 & 0.13 & - & - \\
\hline Australia & 1.80 & 2.68 & 7.00 & 6.67 & 0.38 & 0.02 & 19,154 & 9,991 & 0.79 & 0.02 & 0.63 & 0.29 & 1.13 \\
\hline Austria & 3.52 & 4.00 & 7.00 & 7.47 & 0.73 & 0.16 & 20,049 & 14,824 & 1.25 & 0.02 & 0.13 & 0.07 & 0.51 \\
\hline Bahamas & - & 2.84 & - & 5.98 & 1.11 & 0.12 & 14,126 & 9,225 & 0.71 & 0.03 & 0 & - & - \\
\hline Bahrain & 4.40 & 2.74 & 1.73 & 3.31 & 1.64 & 0.38 & 13,138 & 8,888 & 0.40 & 0.02 & 1.05 & 0.08 & 0.81 \\
\hline Barbados & 2.37 & 2.73 & 6.18 & 6.04 & 1.05 & 0.47 & 11,646 & 9,550 & 0.61 & 0.05 & 0.38 & 0.005 & -0.25 \\
\hline Belgium & 2.73 & 4.33 & 7.00 & 6.33 & 1.43 & 0.66 & 19,495 & 17,665 & 1.31 & 0.02 & 0.46 & 0.09 & 1.08 \\
\hline Canada & 2.09 & 2.72 & 7.00 & 7.04 & 0.70 & 0.03 & 20,858 & 17,389 & 0.91 & 0.02 & 0.65 & 0.33 & 1.37 \\
\hline Chile & 4.57 & 4.32 & 7.00 & 6.62 & 0.52 & 0.04 & 5,660 & 9,127 & 0.66 & 0.06 & 0.83 & 0.08 & 0.45 \\
\hline Costa Rica & 5.48 & 4.71 & 7.00 & 5.72 & 0.77 & 0.14 & 6,428 & 4,243 & 0.24 & 0.06 & 0.07 & 0.003 & -1.24 \\
\hline Czech Rep. & 4.06 & 3.82 & 7.00 & 6.26 & 0.85 & 0.13 & 12,180 & 14,009 & 0.71 & 0.04 & 0.23 & 0.08 & -0.07 \\
\hline Denmark & 2.55 & 3.28 & 7.00 & 6.85 & 0.71 & 0.28 & 21,936 & 17,656 & 0.58 & 0.05 & 0.38 & 0.20 & 0.09 \\
\hline Dominica & - & 3.28 & - & 6.07 & 1.25 & 0.02 & 3,839 & 5,704 & 0.65 & - & - & - & - \\
\hline Finland & 3.14 & 3.19 & 7.00 & 7.11 & 0.57 & 0.10 & 17,945 & 18,372 & 0.72 & - & 0.51 & 0.23 & - \\
\hline France & 3.23 & 4.02 & 6.00 & 7.38 & 0.43 & 0.15 & 19,190 & 14,363 & 1.03 & 0.03 & 0.40 & 0.23 & 0.84 \\
\hline Gabon & - & 4.89 & 2.00 & 3.66 & 1.05 & 0.04 & 6,192 & -938 & 0.19 & - & 0 & - & - \\
\hline Greece & 3.99 & 3.57 & 7.00 & 6.01 & 0.43 & 0.11 & 12,713 & 11,633 & 0.94 & 0.04 & 0.28 & 0.24 & 0.60 \\
\hline Grenada & 2.80 & 3.20 & - & 5.86 & 1.08 & 0.36 & 4,843 & 7,953 & 0.68 & - & - & - & - \\
\hline Hong Kong & 0.73 & 2.55 & - & 5.46 & 2.42 & 1.36 & 16,642 & 17,532 & 1.43 & 0.03 & 2.07 & 1.13 & 5.52 \\
\hline Hungary & 3.42 & 3.94 & 7.00 & 6.38 & 0.82 & 0.10 & 9,513 & 13,291 & 0.82 & 0.05 & 0.13 & 0.10 & -0.18 \\
\hline Iceland & 4.13 & 3.14 & 7.00 & 7.22 & 0.68 & 0.10 & 21,219 & 18,736 & 0.60 & 0.03 & 0.24 & 0.02 & -0.28 \\
\hline Ireland & 2.63 & 2.82 & 7.00 & 7.48 & 1.26 & 0.31 & 14,905 & 18,283 & 0.71 & 0.02 & 0.58 & 0.28 & 1.02 \\
\hline Israel & 3.30 & 2.57 & 7.00 & 5.14 & 0.59 & 0.22 & 14,524 & 10,914 & 0.87 & 0.03 & 0.37 & 0.18 & 0.57 \\
\hline Italy & 4.04 & 4.12 & 7.00 & 6.23 & 0.46 & 0.14 & 18,657 & 12,262 & 0.96 & 0.04 & 0.22 & 0.14 & 0.30 \\
\hline Japan & 2.98 & 3.52 & 7.00 & 6.12 & 0.17 & 0.07 & 19,224 & 10,865 & 2.81 & 0.02 & 0.76 & 0.29 & 3.61 \\
\hline Korea (South) & 3.37 & 3.55 & 6.00 & 6.17 & 0.54 & 0.14 & 8,164 & 11,598 & 0.73 & 0.03 & 0.35 & 0.55 & 1.20 \\
\hline Kuwait & 3.88 & 2.79 & 2.80 & 3.14 & 0.99 & 0.32 & 15,739 & 8,904 & 1.23 & 0.02 & 0.63 & 0.40 & 1.93 \\
\hline Luxembourg & 3.56 & 4.39 & 7.00 & 5.95 & 2.21 & - & 29,370 & - & 1.03 & 0.01 & 1.43 & 0.03 & 2.03 \\
\hline Malaysia & 2.34 & 3.16 & 4.46 & 2.80 & 1.93 & 0.12 & 5,355 & 998 & 1.26 & 0.03 & 1.85 & 0.99 & 4.71 \\
\hline Malta & 2.44 & 3.04 & 7.00 & 6.06 & 1.20 & 0.66 & 9,879 & 15,434 & 1.14 & 0.02 & 0.16 & 0.02 & 0.31 \\
\hline Mauritius & - & 3.01 & 7.00 & 5.11 & 1.27 & 0.40 & 6,340 & 9,347 & 0.66 & 0.04 & 0.30 & 0.02 & -0.20 \\
\hline Mexico & 4.71 & 4.74 & 4.55 & 5.80 & 0.38 & 0.04 & 7,054 & 6,323 & 0.37 & 0.06 & 0.30 & 0.12 & -0.54 \\
\hline Morocco & 4.71 & 3.87 & 2.82 & 3.20 & 0.52 & 0.09 & 2,893 & 6,793 & 0.74 & 0.05 & 0.18 & 0.03 & -0.36 \\
\hline Netherlands & 3.07 & 3.59 & 7.00 & 6.57 & 1.08 & 0.44 & 19,560 & 17,406 & 1.14 & 0.01 & 0.83 & 0.54 & 2.51 \\
\hline New Zealand & 1.58 & 2.55 & 7.00 & 6.77 & 0.62 & 0.04 & 15,794 & 13,363 & 0.95 & 0.03 & 0.44 & 0.13 & 0.68 \\
\hline Norway & 2.95 & 3.17 & 7.00 & 7.13 & 0.71 & 0.11 & 24,161 & 18,055 & 0.79 & 0.03 & 0.28 & 0.18 & 0.34 \\
\hline Oman & - & 4.00 & 1.91 & 3.05 & 0.87 & 0.14 & 9,847 & 4,524 & 0.29 & 0.04 & 0.22 & 0.05 & -0.64 \\
\hline Panama & 5.84 & 4.87 & 6.00 & 5.12 & 1.67 & 0.12 & 4,736 & 3,159 & 0.65 & 0.03 & 0.16 & 0.004 & -0.30 \\
\hline Poland & 4.15 & 4.06 & 6.36 & 6.68 & 0.40 & 0.12 & 7,672 & 14,692 & 0.34 & 0.07 & 0.05 & 0.04 & -1.16 \\
\hline Portugal & 3.93 & 4.21 & 7.00 & 7.29 & 0.60 & 0.17 & 11,534 & 12,840 & 0.89 & 0.04 & 0.23 & 0.07 & 0.09 \\
\hline Qatar & - & 2.90 & 1.00 & 2.64 & 0.79 & 0.15 & - & 6,224 & 0.56 & 0.03 & 0.35 & 0.02 & -0.11 \\
\hline Saudi Arabia & - & 3.80 & 1.00 & 3.38 & 0.78 & 0.03 & 13,881 & 5,175 & 0.61 & 0.03 & 0.34 & 0.06 & 0.01 \\
\hline Singapore & 2.50 & 3.05 & 3.00 & 3.94 & 3.31 & 0.92 & 13,302 & 7,815 & 0.81 & 0.02 & 1.40 & 0.75 & 3.16 \\
\hline South Africa & 1.68 & 2.87 & 7.00 & 4.88 & 0.46 & 0.04 & 9,328 & 8,555 & 1.33 & 0.06 & 1.43 & 0.20 & 2.27 \\
\hline Spain & 5.25 & 4.23 & 7.00 & 6.49 & 0.43 & 0.10 & 13,976 & 11,645 & 1.04 & 0.04 & 0.36 & 0.42 & 1.13 \\
\hline St.Kitts\&Nevis & - & 2.75 & - & 6.19 & 1.27 & 0.33 & 6,738 & 9,611 & 0.72 & - & - & - & - \\
\hline St.Lucia & - & 3.33 & - & 5.86 & 1.22 & 0.35 & 4,052 & 8,005 & 0.59 & - & 0 & - & - \\
\hline St.Vincent\&Gren. & 3.63 & 2.81 & - & 6.02 & 1.27 & 0.39 & 3,637 & 8,926 & 0.44 & - & - & - & - \\
\hline Sweden & 2.98 & 3.18 & 7.00 & 7.08 & 0.65 & 0.07 & 18,364 & 17,723 & 1.21 & 0.02 & 0.71 & 0.42 & 2.00 \\
\hline Switzerland & 3.13 & 4.04 & 7.00 & 6.74 & 0.68 & 0.29 & 24,363 & 14,890 & 1.81 & 0.02 & 1.35 & 1.22 & 5.27 \\
\hline Trinidad\&Tobago & 4.05 & 2.94 & 3.00 & 6.07 & 0.93 & 0.25 & 6,817 & 12,267 & 0.56 & 0.04 & 0.25 & 0.02 & -0.42 \\
\hline Turkey & 2.37 & - & 5.00 & - & 0.37 & 0.09 & 4,625 & - & 0.31 & 0.21 & 0.18 & 0.21 & -2.12 \\
\hline Utd. Arab Em. & - & 2.85 & 3.00 & 2.73 & 1.26 & 0.09 & 27,097 & 5,605 & 0.45 & 0.04 & 0.15 & 0.05 & -0.53 \\
\hline United Kd. & 2.58 & 3.40 & 7.00 & 7.74 & 0.47 & 0.14 & 17,862 & 16,991 & 1.21 & 0.02 & 1.21 & 0.60 & 3.04 \\
\hline United States & 2.62 & 2.70 & 7.00 & 6.56 & 0.20 & 0.02 & 25,142 & 12,181 & 1.28 & 0.04 & 0.94 & 0.84 & 3.08 \\
\hline Uruguay & 4.05 & 4.32 & 7.00 & 6.75 & 0.35 & 0.07 & 6,903 & 10,085 & 0.38 & 0.05 & 0.01 & 0.0003 & -1.09 \\
\hline Venezuela & 6.01 & 4.95 & 5.82 & 5.34 & 0.37 & 0.05 & 5,739 & 2,597 & 0.28 & 0.15 & 0.12 & 0.03 & -1.95 \\
\hline
\end{tabular}


Herger/Hodler/Lobsiger: What Determines Financial Development?

Table A2: continued

Low and Lower Middle Income Countries (as defined by the World Bank)

\begin{tabular}{|c|c|c|c|c|c|c|c|c|c|c|c|c|c|}
\hline \multirow[t]{2}{*}{ Country } & \multicolumn{2}{|c|}{$\begin{array}{l}\text { Contracting } \\
\text { institutions }\end{array}$} & \multicolumn{2}{|c|}{$\begin{array}{l}\text { Predatory } \\
\text { institutions }\end{array}$} & \multicolumn{2}{|c|}{$\begin{array}{c}\text { Trade } \\
\text { openness }\end{array}$} & \multicolumn{2}{|c|}{$\begin{array}{l}\text { GDP per } \\
\text { capita }\end{array}$} & \multirow{2}{*}{$\begin{array}{l}\text { Bank } \\
\text { loans } \\
\\
(9)\end{array}$} & $\begin{array}{l}\text { Net } \\
\text { interest }\end{array}$ & $\begin{array}{l}\text { Stock } \\
\text { market }\end{array}$ & $\begin{array}{l}\text { Value } \\
\text { stock }\end{array}$ & $\begin{array}{l}\text { Finan } \\
\text { dev. }\end{array}$ \\
\hline & $\begin{array}{l}\text { Actu. } \\
\text { (1) }\end{array}$ & $\begin{array}{l}\text { Constr. } \\
\text { (2) }\end{array}$ & $\begin{array}{l}\text { Actu. } \\
\text { (3) }\end{array}$ & $\begin{array}{l}\text { Constr. } \\
\text { (4) }\end{array}$ & $\begin{array}{l}\text { Actu. } \\
\text { (5) }\end{array}$ & $\begin{array}{l}\text { Constr. } \\
(6)\end{array}$ & $\begin{array}{l}\text { Actu. } \\
\text { (7) }\end{array}$ & $\begin{array}{l}\text { Constr. } \\
(8)\end{array}$ & & (10) & (11) & (12) & \\
\hline Algeria & 4.62 & 3.84 & 2.45 & 3.28 & 0.63 & 0.06 & 4,953 & 5,830 & 0.54 & 0.04 & 0 & - & - \\
\hline Angola & - & 4.75 & 3.00 & 4.06 & - & 0.02 & 1,954 & 2,108 & 0.20 & - & 0 & - & - \\
\hline Bangladesh & 3.24 & 3.72 & 4.72 & 3.71 & 0.26 & 0.09 & 1,120 & 5,785 & 0.27 & 0.02 & 0.03 & 0.007 & -0.79 \\
\hline Benin & 4.46 & 4.56 & 5.00 & 3.68 & 0.52 & 0.06 & 801 & 1,530 & 0.11 & 0.04 & 0 & - & - \\
\hline Bhutan & - & 4.02 & 2.00 & 4.93 & 0.75 & 0.03 & - & 6,955 & 0.07 & - & 0.09 & - & - \\
\hline Bolivia & 5.75 & 4.94 & 7.00 & 4.72 & 0.43 & 0.02 & 2,124 & 3,614 & 0.53 & 0.06 & 0.03 & 0.0003 & -0.92 \\
\hline Brazil & 3.06 & 4.63 & 6.00 & 5.37 & 0.18 & 0.02 & 6,110 & 3,084 & 0.78 & 0.14 & 0.21 & 0.13 & -0.94 \\
\hline Bulgaria & 4.57 & 3.66 & 7.00 & 5.59 & 0.79 & 0.13 & 5,747 & 12,072 & 0.78 & 0.05 & 0.03 & 0.001 & -0.52 \\
\hline Burkina Faso & 4.64 & 4.38 & 2.00 & 3.24 & 0.47 & 0.02 & 824 & 1,773 & 0.10 & 0.05 & 0 & - & - \\
\hline Burundi & - & 4.69 & 2.14 & 4.37 & 0.14 & 0.03 & 700 & 654 & 0.24 & 0.09 & 0 & - & - \\
\hline Cameroon & 4.77 & 4.76 & 2.00 & 3.22 & 0.47 & 0.15 & 1,912 & 821 & 0.23 & 0.05 & 0 & - & - \\
\hline Cen. Afr. Rep. & - & 4.58 & 3.91 & 3.46 & 0.62 & 0.03 & 1,190 & 585 & 0.12 & - & 0 & - & - \\
\hline Chad & - & 4.51 & 1.90 & 2.92 & 0.57 & 0.01 & 836 & 1,702 & 0.12 & _- & 0 & - & - \\
\hline Colombia & 4.11 & 5.07 & 6.36 & 5.04 & 0.39 & 0.06 & 5,065 & 1,339 & 0.37 & 0.08 & 0.13 & 0.01 & - \\
\hline Comoros & - & 3.87 & 4.30 & 3.05 & 0.55 & 0.12 & 1,695 & 2,649 & 0.18 & - & - & - & - \\
\hline Congo (Zaire) & - & 4.90 & 1.00 & 3.39 & 0.11 & 0.02 & 1,381 & $-1,325$ & 0.13 & - & 0 & - & - \\
\hline Congo Rep. & - & 4.89 & 3.10 & 3.44 & 0.67 & 0.04 & 830 & -914 & 0.22 & 0.13 & 0 & - & - \\
\hline Djibouti & - & 4.37 & 2.18 & 1.93 & 1.71 & 0.11 & 1,844 & 692 & 0.49 & - & - & - & - \\
\hline Dominican Rep. & 4.08 & 4.67 & 5.46 & 5.78 & 0.41 & 0.09 & 4,084 & 5,857 & 0.28 & 0.09 & 0 & - & - \\
\hline Ecuador & 4.92 & 5.14 & 6.91 & 4.59 & 0.65 & 0.08 & 3,074 & 515 & 0.28 & - & 0.09 & 0.009 & - \\
\hline Egypt & 3.79 & 2.52 & 3.00 & 3.62 & 0.47 & 0.09 & 2,534 & 7,437 & 0.90 & 0.02 & 0.14 & 0.04 & 0.09 \\
\hline El Salvador & 4.60 & 3.33 & 5.00 & 5.93 & 0.48 & 0.24 & 3,827 & 7,241 & 0.32 & 0.05 & 0.09 & 0.002 & -0.97 \\
\hline Gambia & - & 3.14 & 2.82 & 2.09 & 2.16 & 0.10 & 1,550 & 2,466 & 0.07 & - & 0 & - & - \\
\hline Ghana & 2.65 & 3.22 & 3.30 & 3.73 & 0.89 & 0.05 & 1,594 & 2,555 & 0.21 & 0.10 & 0.15 & 0.004 & -1.58 \\
\hline Guatemala & 5.68 & 4.72 & 4.36 & 5.20 & 0.41 & 0.16 & 3,381 & 4,965 & 0.17 & 0.08 & 0.01 & 0.0003 & -1.59 \\
\hline Guinea & - & 4.41 & 2.46 & 2.27 & 0.47 & 0.04 & 1,678 & 483 & 0.07 & - & 0 & - & - \\
\hline Guinea Bissau & - & 4.47 & 3.78 & 3.05 & 1.02 & 0.06 & 781 & 1,602 & 0.15 & - & - & - & - \\
\hline Guyana & - & 3.20 & 4.27 & 4.69 & - & 0.06 & 3,339 & 3,006 & - & 0.05 & 0 & - & - \\
\hline Haiti & - & 4.35 & 4.50 & 5.38 & 0.29 & 0.08 & 2,048 & 5,703 & 0.29 & 0.08 & 0 & - & - \\
\hline Honduras & 4.90 & 4.61 & 5.00 & 5.93 & 0.96 & 0.16 & 2,314 & 5,761 & 0.30 & 0.09 & 0.08 & 0.01 & -1.40 \\
\hline India & 3.34 & 2.78 & 7.00 & 4.64 & 0.20 & 0.05 & 1,534 & 6,482 & 0.48 & 0.03 & 0.27 & 0.21 & 0.03 \\
\hline Indonesia & 3.90 & 4.45 & 2.82 & 1.99 & 0.79 & 0.04 & 2,017 & $-1,119$ & 0.53 & 0.06 & 0.20 & 0.09 & -0.55 \\
\hline Iran & - & 3.99 & 3.36 & 2.93 & 0.50 & 0.04 & 5,089 & 6,048 & 0.55 & 0.05 & 0.14 & - & - \\
\hline Iraq & - & 2.57 & 1.00 & 3.44 & 0.14 & 0.06 & - & 8,310 & - & - & - & - & - \\
\hline Ivory Coast & 3.65 & 4.60 & 2.80 & 3.02 & 0.68 & 0.04 & 1,742 & 429 & 0.33 & 0.06 & 0.07 & 0.002 & -1.08 \\
\hline Jamaica & 2.34 & 2.87 & 7.00 & 5.84 & 1.12 & 0.13 & 3,307 & 7,816 & 0.30 & - & 0.33 & 0.03 & - \\
\hline Jordan & 3.52 & 3.97 & 3.00 & 3.06 & 1.34 & 0.23 & 3,693 & 7,318 & 0.96 & 0.03 & 0.66 & 0.11 & 0.90 \\
\hline Kenya & 3.09 & 3.47 & 3.00 & 3.36 & 0.56 & 0.03 & 956 & 334 & 0.53 & 0.07 & 0.16 & 0.005 & -0.88 \\
\hline Laos & - & 4.10 & 3.00 & 4.65 & 0.44 & 0.06 & 1,116 & 4,830 & 0.10 & - & - & - & - \\
\hline Madagascar & 4.32 & 4.31 & 5.90 & 4.07 & 0.78 & 0.06 & 864 & 4,448 & 0.22 & 0.09 & 0 & - & - \\
\hline Malawi & 2.95 & 3.17 & 3.55 & 3.83 & 0.62 & 0.06 & 511 & 3,915 & 0.18 & 0.12 & 0.02 & 0.0001 & -2.00 \\
\hline Mali & 4.72 & 4.22 & 4.60 & 2.48 & 0.53 & 0.02 & 687 & 1,965 & 0.13 & 0.07 & 0 & - & - \\
\hline Mauritania & - & 4.13 & 3.00 & 2.51 & 1.01 & 0.03 & 1,488 & 2,824 & 0.29 & 0.08 & 0 & - & - \\
\hline Mongolia & - & 3.60 & 6.64 & 5.95 & 1.37 & 0.03 & 1,536 & 12,444 & 0.25 & - & 0.04 & 0.009 & - \\
\hline Mozambique & 4.49 & 4.41 & 3.64 & 3.85 & 0.42 & 0.02 & 629 & 3,494 & 0.07 & 0.11 & 0 & - & - \\
\hline Myanmar & - & 2.82 & 3.00 & 4.77 & - & 0.10 & 7,371 & - & 0.34 & 0.07 & - & - & - \\
\hline Nepal & 4.19 & 4.04 & 6.00 & 4.79 & 0.50 & 0.07 & 947 & 7,273 & 0.33 & 0.04 & 0.05 & 0.002 & -0.96 \\
\hline Nicaragua & 4.96 & 4.72 & 6.09 & 5.22 & 0.54 & 0.13 & 2,729 & 4,271 & - & 0.06 & 0 & - & - \\
\hline Niger & 4.32 & 4.21 & 4.40 & 2.52 & 0.43 & 0.01 & 868 & 1,801 & 0.12 & - & 0 & - & - \\
\hline Nigeria & 3.19 & 3.25 & 1.80 & 2.96 & 0.45 & 0.04 & 791 & 2,120 & 0.22 & 0.08 & 0.07 & 0.002 & -1.45 \\
\hline Pakistan & 3.76 & 2.81 & 5.73 & 2.82 & 0.31 & 0.14 & 1,403 & 7,421 & 0.52 & 0.03 & 0.15 & 0.10 & -0.34 \\
\hline Papua New G. & - & 3.10 & 7.00 & 4.53 & 0.94 & 0.04 & 2,082 & 2,983 & 0.33 & 0.06 & 0 & - & - \\
\hline Paraguay & 5.91 & 4.50 & 6.18 & 5.40 & 0.83 & 0.03 & 4,207 & 6,050 & 0.26 & 0.10 & 0.03 & 0.002 & -1.67 \\
\hline Peru & 5.60 & 4.99 & 3.70 & 4.76 & 0.30 & 0.05 & 4,446 & 2,298 & 0.17 & 0.11 & 0.15 & 0.04 & -1.62 \\
\hline Philippines & 5.00 & 4.64 & 6.18 & 4.75 & 1.01 & 0.11 & 3,549 & 3,744 & 0.55 & 0.05 & 0.53 & 0.16 & 0.22 \\
\hline Romania & 4.42 & 3.60 & 5.46 & 6.14 & 0.01 & 0.01 & 5,424 & 13,141 & 0.32 & 0.13 & 0.01 & 0.005 & -1.89 \\
\hline Rwanda & - & 4.72 & 1.70 & 4.26 & 0.63 & 0.03 & 1,067 & 273 & 0.15 & 0.11 & 0 & - & - \\
\hline Senegal & 4.72 & 4.31 & 3.27 & 2.31 & 0.75 & 0.05 & 1,303 & 1,306 & 0.27 & 0.05 & 0 & - & - \\
\hline Sierra Leone & - & 3.20 & 2.14 & 2.58 & 0.27 & 0.06 & 783 & 1,553 & 0.43 & 0.10 & 0 & - & - \\
\hline Somalia & - & 3.16 & 1.00 & 1.81 & 0.04 & 0.03 & - & 956 & - & - & - & - & - \\
\hline Sri Lanka & 3.78 & 3.01 & 5.00 & 4.21 & 0.76 & 0.18 & 2,173 & 4,002 & 0.36 & 0.04 & 0.15 & 0.02 & -0.80 \\
\hline Sudan & - & 3.07 & 1.00 & 2.72 & 0.17 & 0.03 & 1,234 & 3,052 & 0.13 & 0.07 & 0 & - & - \\
\hline Suriname & - & 5.08 & 6.36 & 3.76 & 1.09 & 0.05 & - & -66 & 0.50 & - & 0 & - & - \\
\hline Syria & - & 3.87 & 1.18 & 3.52 & 0.68 & 0.11 & 2,671 & 7,913 & 0.47 & - & 0 & - & - \\
\hline Tanzania & 3.82 & 3.43 & 3.00 & 3.09 & 0.48 & 0.03 & 469 & 1,142 & 0.23 & 0.08 & 0 & - & - \\
\hline Thailand & 3.14 & 4.22 & 6.27 & 4.30 & 0.98 & 0.12 & 3,915 & 4,184 & 1.27 & 0.03 & 0.52 & 0.37 & 1.64 \\
\hline Togo & - & 4.54 & 1.89 & 3.67 & 0.75 & 0.07 & 1,539 & 1,343 & 0.24 & 0.06 & - & - & - \\
\hline Tunisia & 2.53 & 3.49 & 7.00 & 4.10 & 0.93 & 0.15 & 4,354 & 10,001 & 0.68 & 0.03 & 0.11 & 0.01 & -0.37 \\
\hline Uganda & 2.61 & 3.71 & 2.46 & 3.17 & 0.33 & 0.02 & 937 & -187 & 0.09 & 0.10 & 0 & - & - \\
\hline Zambia & 2.13 & 3.20 & 4.64 & 4.18 & 0.58 & 0.03 & 925 & 4,416 & 0.59 & 0.15 & 0.04 & 0.001 & -1.76 \\
\hline Zimbabwe & 3.11 & 2.81 & 3.00 & 5.01 & 0.59 & 0.05 & 2,393 & 6,836 & 0.49 & 0.08 & 0.25 & 0.02 & -0.83 \\
\hline
\end{tabular}




\section{References}

Acemoglu, D., and S. Johnson (2005). Unbundling Institutions. Journal of Political Economy 113 (5): 949-995.

Acemoglu, D., S. Johnson, and J. A. Robinson (2001). The Colonial Origins of Comparative Development: An Empirical Investigation. American Economic Review 91 (5): 1369-1401.

Ades, A., and R. Di Tella (1999). Rents, Competition, and Corruption. American Economic Review 89 (4): 982-993.

Alesina, A., A. Devleeschauwer, W. Easterly, S. Kurlat, and R. Wacziarg (2003). Fractionalization. Journal of Economic Growth 8 (2): 155-194.

Beck, T., A. Demirguc-Kunt, and R. Levine (2000). A New Database on Financial Development and Structure. World Bank Economic Review 14 (3): 597-605.

Beck, T., A. Demirguc-Kunt, and R. Levine (2003). Law, Endowments, and Finance. Journal of Financial Economics 70 (2): 137-181.

Djankov, S., R. La Porta, F. Lopez-de-Silanes, and A. Shleifer (2002). The Regulation of Entry. Quarterly Journal of Economics 67 (1): 1-37.

Do, Q. T., and A. A. Levchenko (2007). Comparative Advantage, Demand for External Finance, and Financial Development. Journal of Financial Economics 86 (3): 796-834.

Dollar, D., and A. Kraay (2003). Institutions, Trade, and Growth. Journal of Monetary Economics 50 (1): 133-162.

Easterly, W., and R. Levine (1997). Africa's Growth Tragedy: Policies and Ethnic Divisions. Quarterly Journal of Economics 112 (4): 1203-1250.

Easterly, W., and R. Levine (2003). Tropics, Germs, and Crops: How Endowments Influence Economic Development. Journal of Monetary Economics 50 (1): 3-39.

Feeney, J., and A. L. Hillman (2004). Trade Liberalization through Asset Markets. Journal of International Economics 64 (1): 151-167.

Frankel, J. A., and D. Romer (1999). Does Trade Cause Growth? American Economic Review 89 (3): 379-399.

Frankel, J. A., and A. Rose (2002). An Estimate of the Effect of Common Currencies on Trade and Income. Quarterly Journal of Economics 117 (2): 437-466.

Gallup, J. L., J. D. Sachs, and A. D. Mellinger (1999). Geography and Economic Development. Center for International Development Working Paper 1. Harvard University, Cambridge, Mass.

Hall, R. E., and C. I. Jones (1999). Why Do Some Countries Produce So Much More Output per Worker Than Others? Quarterly Journal of Economics 114 (1): 83-116.

Huang, Y., and J. Temple (2005). Does External Trade Promote Financial Development? Bristol Economics Discussion Paper 05/575. University of Bristol, Bristol.

Landes, D. (1998). The Wealth and Poverty of Nations. New York: Norton. 
La Porta, R., F. Lopez-De-Silanes, A. Shleifer, and R. W. Vishny (1997). Legal Determinants of External Finance. Journal of Finance 52 (3): 1131-1150.

La Porta, R., F. Lopez-De-Silanes, A. Shleifer, and R. W. Vishny (1999). The Quality of Government. Journal of Law, Economics, and Organization 15 (1) : 222279.

Levine, R. (1997). Financial Development and Economic Growth: Views and Agenda. Journal of Economic Literature 35 (2): 688-721.

Levine, R. (2005). Finance and Growth: Theory and Evidence. In P. Agihion and S. Durlauf (eds.), Handbook of Economic Growth. Amsterdam: Elsevier.

Lucas, R. E. (1988). On the Mechanics of Economic Development. Journal of Monetary Economics 22 (1): 3-42.

North, D. (1981). Structure and Change in Economic History. New York: Norton.

North, D. (1990). Institutions, Institutional Change, and Economic Performance. Cambridge: Cambridge University Press.

Rajan, R. G., and L. Zingales (2003). The Great Reversals: The Politics of Financial Development in the Twentieth Century. Journal of Financial Economics 69 (1): 5-50.

Rodrik, D., A. Subramanian, and F. Trebbi (2004). Institutions Rule: The Primacy of Institutions over Geography and Integration in Economic Development. Journal of Economic Growth 9 (2): 131-165.

Sachs, J. (2003). Institutions Don't Rule: Direct Effects of Geography on Per Capita Income. NBER Working Paper 9490. National Bureau of Economic Research, Cambridge, Mass.

Staiger, D., and J. H. Stock (1997). Instrumental Variables Regression with Weak Instruments. Econometrica 65 (3): 557-586

Stulz, R. M., and R. Williamson (2003). Culture, Openness, and Finance. Journal of Financial Economics 70 (2): 313-349.

Svaleryd, H., and J. Vlachos (2002). Markets for Risk and Openness to Trade: How Are They Related? Journal of International Economics 57 (2): 369-395. 